\title{
„Kiugrás” az ismeretlenbe. Az 1944-ben Mezőcsokonya területén lezuhant angol szállító repülögép és legénységének története
}

\author{
NAGY GÁBOR
}

Janus Pannonius Múzeum, H-7621 Pécs, Széchenyi tér 9., e-mail: nagygabor42@hotmail.com

\begin{abstract}
NAGY, G.: "Jump" into the unknown. The story of a British cargo plane and its' crewmembers, crashed in Mezőcsokonya, Hungary in 1944.

Abstract: On the night 3/4 July 1944 a Handley Page Halifax Mk II cargo plane, belonged to the Royal Air Force 148. squadron crashed near the village Mezőcsokonya, Hungary. All eight crewmembers lost their lives. They flew a double coded mission, first to drop supplies to Yugoslavian partisans then to drop four secret SOE agents (Special Operations Executive) over Hungary. The agents would have had to set up an underground resistance group which could have helped and supported Hungary to leave the Axis. Almost twenty years of research making interviews with eyewitnesses and relatives, studying documents, and making investigation and field research for remains of the plane finally revealed the full and detailed story of the eight crewmembers, the four agents and their mission.
\end{abstract}

Keywords: Second World War, Royal Air Force, Halifax, SOE agents, 148. sqn., wreckage, field survey

1997 nyara volt. Egy kis Somogy megyei település, Mezőcsokonya felé tartottunk párommal. Alig néhány hónapja kezdtem neki legújabb kedvtelésemnek, a repüléstörténeti kutatásoknak. Ekkorra már közel 10 éve foglalkoztam a RAF (Royal Air Force - Királyi Légierő) pilótáinak történetével, de nem a magyarországi légi események kapcsán. Addig csupán néhány olyan helyszínt látogattam meg, ahol amerikai repülősök jártak szerencsétlenül, így ez az út kiváltképp izgalmasnak ígérkezett, hiszen ez alkalommal nem a könyvek lapjairól, hanem a tényleges helyszínen testközelből ismerhettem meg néhány angol repülős történetét és sorsát.

A rendelkezésemre álló dokumentumok szűkszavú ténymegállapításán és rideg adatain kívül, nem sok információm volt az eseményröl. Ezekből kiderült, hogy 1944. július 3/4-ének éjjelén Mezőcsokonya felett egy német éjszakai vadász lelött egy angol Handley Page Halifax Mk II-es repülőgépet. A 148. század állományába tartozó, FS-S kódjelü, JP286 szériaszámú gép (1. ábra) a falutól távol, egy szőlő ültetvényre zuhant és elégett. Nyolcfőnyi legénysége életét vesztette, akik a következők voltak:

Surry Philip Victor Bird őrnagy - századparancsnok pilóta - 24 éves

Peter Lake fötörzsőrmester - navigátor - 21 éves

Harold Pearson hadnagy - fedélzeti mérnök - 22 éves

Arthur Archer Lee fötörzsőrmester - rádiós-lövész - 35 éves

Donald David Charles Stewart tiszthelyettes - navigátor -21 éves

Kenneth Peter Mc Leod Cran - föhadnagy - lövész -35 éves
Radford Ronald - fötörzsőrmester - lövész - 20 éves

Tilmont Marcel - tiszthelyettes - lövész - 24 éves

A Veszprémi Egyházmegye Halotti Anyakönyvébe tett bejegyzés így írt az eseményröl:

„1944. július 4-én hajnali 1 órakor lelött Halifax mintájú angol bombázó 8 fönyi személyzetét a katonai parancsnokság utasítására eltemettem. Egyik személyazonosságát megállapították: „Philip Victor vezető" Ennél Mária és szt. Domonkos érem volt. Így feltehető, hogy katolikus volt. A többiek darabokra szakadtak és elégtek. Temetés: Mezőcsokonya, Nyíres-puszta július 5. közös sírba helyeztettek."

A faluba érve érdeklődni kezdtem és néhány sikertelen próbálkozás után a hetvenes éveiben járó Filó Ferenc azt felelte, hogy mindent tud az eseményről és meg is tudja mutatni hol történt.

A faluból a helyszínre vezető út teljesen elhanyagolt volt. Az alig 2,5 km-es út majd fél órába telt, aminek a végén egy kerítéssel határolt területhez értünk. Ez volt az egykori tragédia helyszíne. Az akkori szőlősnek már nyoma sem volt. A területet sürü növényzet borította, tüskés bokrok és fiatal fák. Az áthatolhatatlan vegetációban esély sem volt nézelődésre, vagy keresgélésre. A terület szélén megállva így mesélt a történtekről:

„19 éves voltam. Éjjel hatalmas robbanásra ébredtünk. Reggel kimentünk megnézni a roncsokat. A repüló a szőlöültetvényre esett, de elötte nekirepült a közelben lévő magas nyárfáknak. Az egyik darabja még évekig ott volt fennakadva az ágak között. Ma már nincsenek meg ezek a fák. Engem, mint leventét utasítottak a roncs őrzésére. Egy flóbert puskát nyomtak a kezembe és meghagyták, hogy senkit se engedjek a gép közelébe. A roncs nagy területen szóródott szét. Életemben nem láttam még annyi margarint, hatalmas tábla csokoládét, rengeteg méterárut és sok más élelmiszert, ami a roncsok körül hevert. 24 órás váltással voltunk szolgálatban. Esténként a szárny egy jókora megmaradt darabján aludtunk. Csak később fedeztük fel, hogy alatta van az egyik összeégett holttest. A roncs őrzése majdnem az életembe került. Egy nap német katonák álltak meg a kerítésen kívül autóval. Átugráltak s odajöttek, hogy elvigyenek ezt s azt. Én a parancs értelmében rájuk fogtam a fegyvert és mondtam, hogy nem lehet. Erre felhúzták a fegyvereiket és azt mondták, hogy ne avatkozzak bele, és ha nem engedem, akkor agyonlö-

1 Mohos Nándor kutatása 


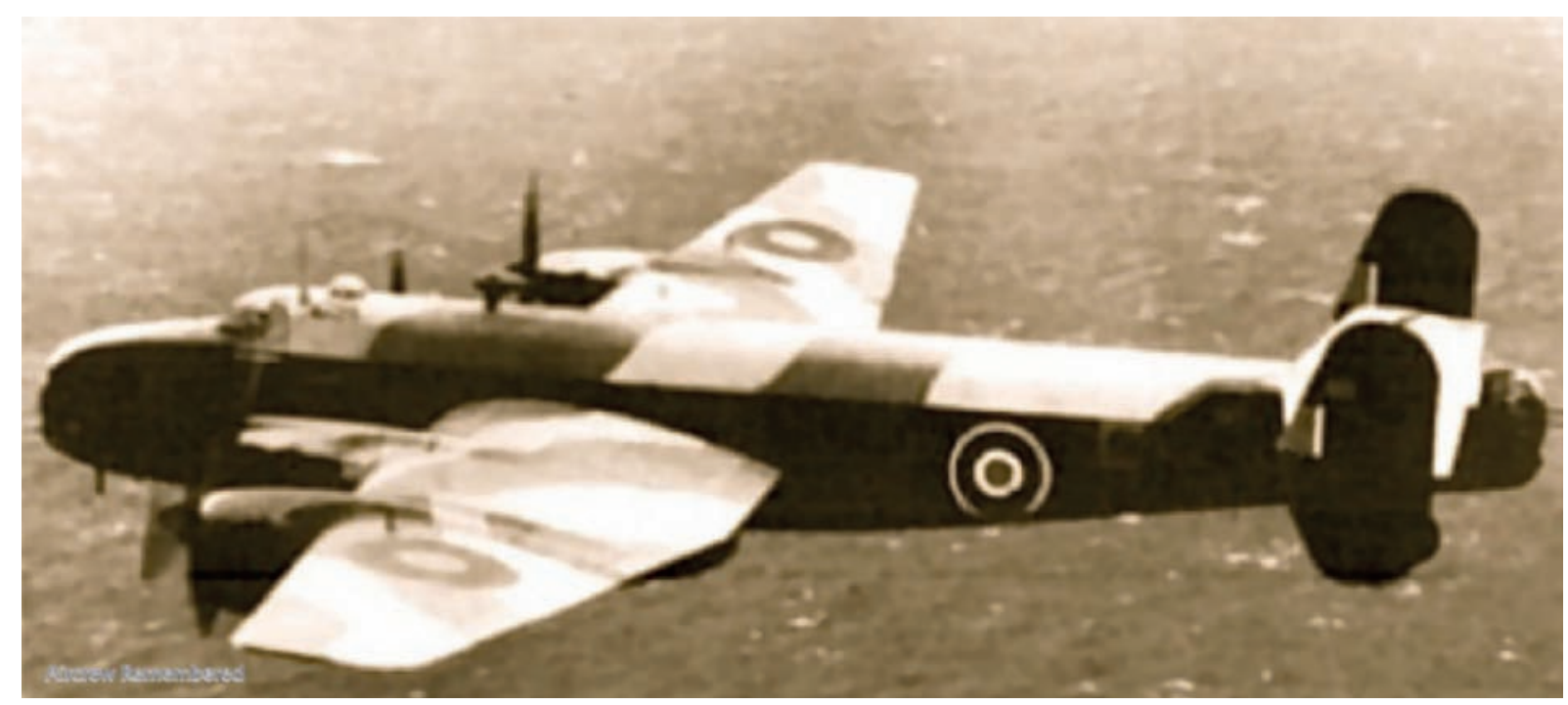

1. ábra. Az egyetlen ismert fotó a szerencsétlenül járt FS-S jelü JP286 szériaszámú Halifax Mk II-esröl.

(Forrás: http://aircrewremembered.com/bird-surray.html).

nek. Így hát hagytam őket. Később a taszári reptérről egy pilóta föhadnagy érkezett, aki azt mondta ő lőtte le a repülöt. Felültetett a szárnyra majd az egyik motorra és készített egy-egy fotót. Azt igérte hoz belölük, de soha nem jött vissza. A nyolc repülős összeégett holttestét szekérrel vitték a falu temetöjébe, ahol közös sírba temették őket. Sírjaikat tisztességgel gondozták. A háború után eljöttek értük, kihantolták őket és elvitték. Azokat a helybélieket, akik a sírt gondozták az angolok megjutalmazták."

Az évek múlásával, még ha apránként is, de gyültek az adatok. A RAF Múzeumhoz és különböző veterán szervezetekhez írt leveleim nem maradtak eredmény nélkül. A 2000-es évek elején levelet kaptam a gép rádiósa, Arthur Archer Lee testvérétől, aki fényképeket és dokumentumokat is küldött.

Az internet térhódításával új távlatok nyíltak. Életre hívtak egy honlapot, amely a 148. század történetével foglalkozik, ahol a tagok szinte naponta közölnek új információkat és dokumentumokat. Én is hamar a tagok között tudhattam magamat és az addig „rejtélyes” eset egyre gyorsabban bontakozott ki. Mindezt pedig az koronázta meg, amikor levelet kaptam a gép pilótájának lányától, Penelope Bird Barnardtól.

Az összegyüjtött anyagokból közel 20 év kutatása után végül egy olyan történet bontakozott ki, ami a legelképesztőbb volt az általam kutatott esetek közül.

\section{Egyedül, a sötétség leple alatt}

A németek által megszállt országok területén titkos ellenállási mozgalmak szerveződtek, amelyeket a szövetséges légierő a kezdetektől fogva megpróbált támogatni, ám a hatalmas távolság miatt a siker korlátozott volt.

1943 őszére Olaszország déli területeinek felszabadításával angol és amerikai repülőezredek vették birtokba a németek által elhagyott reptereket, ahonnan már Lengyelország, Jugoszlávia, Görögország és
Magyarország is elérhető távolságba került. A RAF a partizánok és a földalatti mozgalmak megsegítésére illetve ügynökök eljuttatására különleges feladatú egységeket állított fel. Közülük talán a legismertebb a teljes egészében lengyel személyzetből álló 1586. Flight volt, akikre többek között a Varsói Felkelés légi támogatásának oroszlánrésze is hárult. Hamar világossá vált, hogy egyedül nem fogják tudni ellátni a feladatot, így további egységeket is bevontak, köztük a 148. századot. A túlnyomó részt teherszállításra átalakított Handley Page Halifax gépekkel müködő századok támaszpontja az olaszországi Brindisiben volt, ahonnan éjszakánként magányosan, vadászkíséret nélkül indultak útnak. A kockázat óriási volt. Az elsötétített városok felett már a navigáció sem volt egyszerü, de az igazi veszélyt a mindenütt ólálkodó német éjszakai vadászok jelentették. A célterületet elérve a gépeknek alacsonyra kellett ereszkedniük és olykor többször is át kellett húzniuk a terület felett, mire kioldhatták terhüket. Ha sikerült célba juttatni a szállítmányt a veszély még korántsem ért véget. A hazaút a megszállt országok felett újabb izzasztó órákba telt, kémlelve az őket körülvevő sötétséget, amelyböl bármelyik pillanatban előbukkanhatott egy prédájára váró éjszakai vadász (2. ábra).

Az ellátmányok szállítása mellett azonban egy olyan feladat is rájuk hárult, amelyek egyes dokumentumai nem csak a háborút követő évtizedekben, de még ma is szigorúan titkos minősítésűek: titkos ügynökök eljutatása a megszállt területekre. Az ilyen bevetéseket az úgynevezett SOE (Special Operations Executive - Különleges Hadműveleti Csoport) részleg dolgozta ki, az ügynökök ledobásáért pedig az erre kijelölt századok feleltek. A titoktartás rendkívül szigorú volt. Még a repülőszemélyzet sem tudott semmit az ügynökök személyéről, céljáról és feladatáról, sőt legtöbbször nem is látták őket! Az ilyen bevetéseknél már a gépbe szállás is más volt, mint a megszokott. 


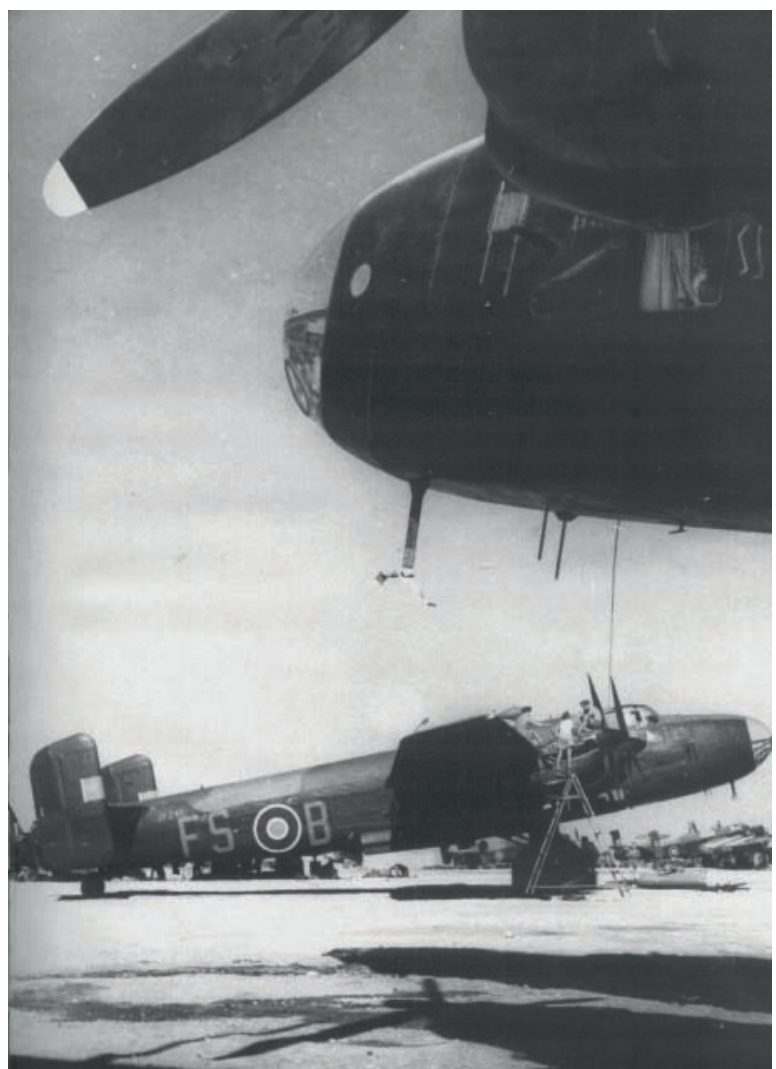

2. ábra. A 148. század FS-B jelü JP246 szériaszámú Halifax szállitógépe az olaszországi Brindisi repterén. (Forrás: http://myweb.tiscali.co.uk/hphalifax/148jp246.htm).

A repülőgépbe legelsőként a személyzet mászott be, majd amikor mindenki a fedélzeten volt, a titkos küldetés tagjai is elfoglalták a helyüket, rendszerint a gép hátuljában.

\section{Az akció fedőneve: DEERHURST}

Magyarország már 1943 elejétől titkos puhatolózó tárgyalásokat folytatott a szövetségesekkel a háborúból való kiugrás lehetőségeiről. A szövetségesek ennek megfelelően több alkalommal is igyekeztek ellenállási mozgalmat kiépíteni az országban. A SOE több titkos küldetést is szervezett az ország területére, amelyek egyike volt a DEERHURST fedőnevü bevetés. Az akció célja az volt, hogy kapcsolatot létesítsenek azzal az állítólag „300 főből” álló csoporttal, amit egy volt magyar tiszt állított fel, és akiknek föhadiszállása a Balatontól északnyugatra lévő sűrü erdőségben volt. A bevetést eredetileg a SOE 31 éves tisztje Richard John Moncrieff Wright őrnagy szervezte meg, akik Veszprémtől 45 mérföldre északnyugatra értek volna földet.

Mindeközben Boughey alezredes Pécs térségébe tervezett egy bevetést, amit végül a városban jelen lévő német SS osztag jelenléte miatt töröltek. Végül a két csoportot összevonták és egy bevetésként szervezték meg, ami szintén a DEERHURST fedőnevet kapta és vezetője Boughey alezredes lett. Edward

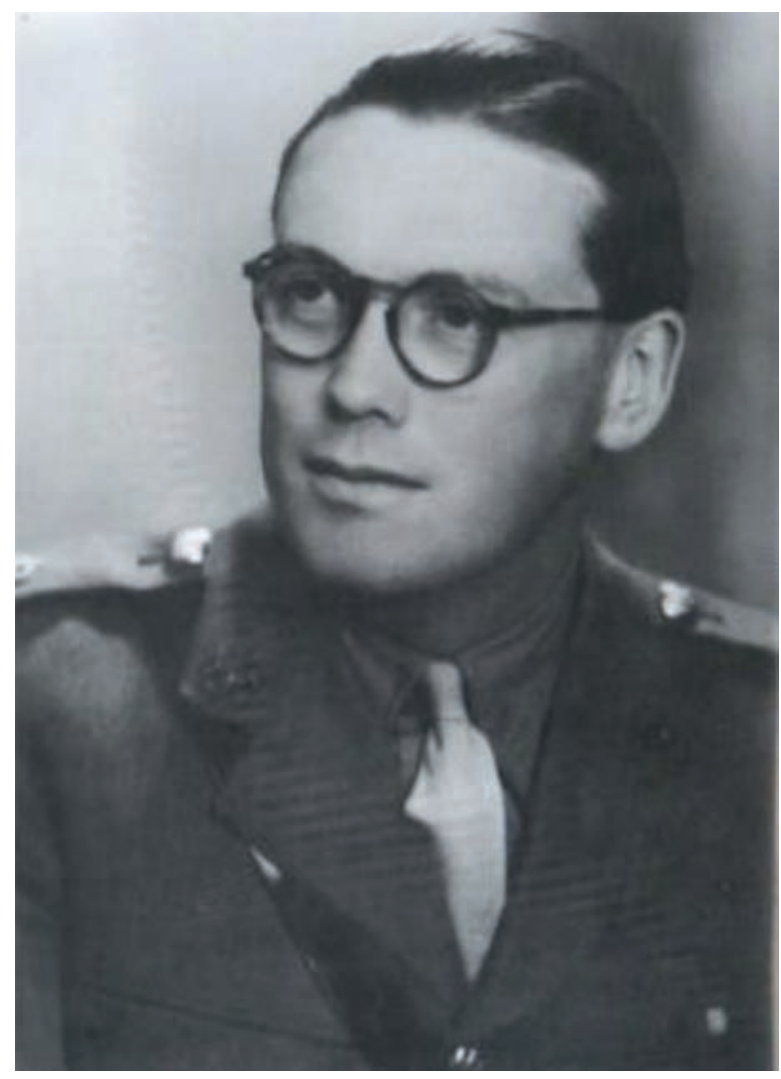

3. ábra. Edward Peter Fletcher Boughey alezredes a SOE ügynöke. (Forrás: https://en.wikipedia.org/wiki/ Peter_Boughey)

Peter Fletcher Boughey alezredes, a SOE egyik legtapasztaltabb tisztje volt. 1940-ben Jugoszláviában csatlakozott a szolgálathoz, így a szervezet megalakulásának kezdetétől a tagja volt (3. ábra).

Terveik szerint, ha földetérésük után a helyzet kedvezőnek bizonyul, akkor Wright és csapata a hegyekben maradnak, Boughey pedig a Pécstől vagy a Balatontól délre eső területekre szivárog be.

Terveik azonban szöges ellentétben álltak a SOE néhány héttel korábban készített elemzésével, amely megállapította, hogy Magyarországon semmiféle ellenállási mozgalom nincs, az országban nem dúlnak harcok, nincsenek számottevő károk, és nem tartozik a leigázott országok közé. Mi több az elmúlt négy évben a Németországgal való szövetségböl csak profitáltak, miközben a lakosság átlag életszínvonala továbbra is nőtt.

Mindezt Basil Davidson a SOE legtapasztaltabb közép-európai ügynöke is megerösítette, aki 1943 augusztusa óta partizánalakulatokkal együtt tevékenykedett Boszniában, és akit a SOE korábban Magyarországra küldött, hogy próbáljon felkelést szervezni. Davidson azonban dolga végezetlenül tért vissza Fruska Gorába, mivel úgy látta, hogy a helyzet erre nem alkalmas. Jelentése szerint az országban erőteljes a német és magyar kémelhárítás, a rendőrség hatékony, a magyar lakosság közönyös, de inkább ellenséges, és nincs magja ellenállási mozgalomnak. Továbbá a 


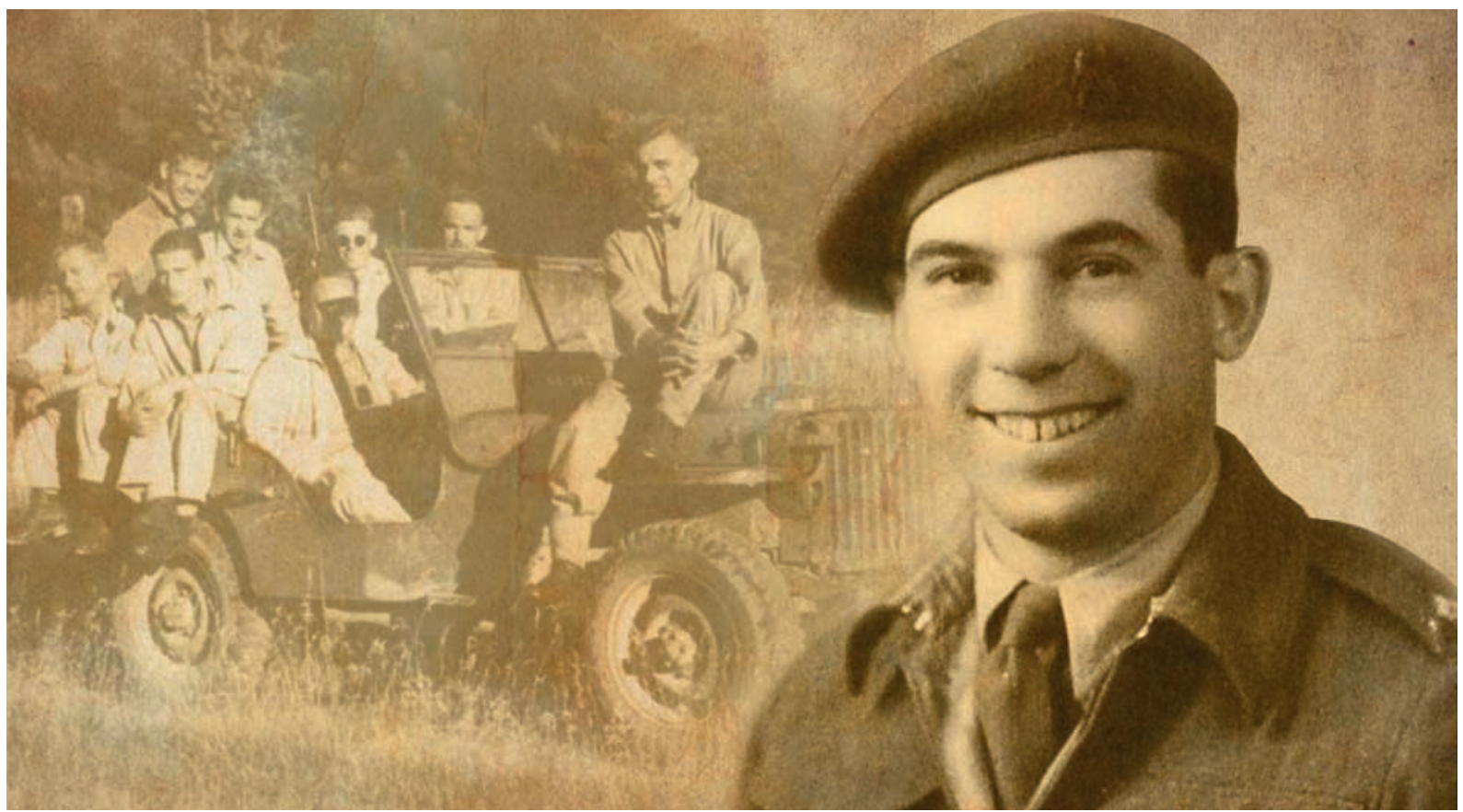

4. ábra. Vass Francis Alexander hadnagy, a magyar származású kanadai SOE ügynök.

(Forrás:http://www.cbc.ca/xcompany/dispatches/brave-hungarian-canadian-finds-no-luck-in-war)

magyar megszállók által elkövetett brutalitások miatt a teljes szerb lakosság ellenük fordult, ezen kívül Voj Vodina térségében jugoszláv árulók tevékenykednek, és hamis magyar iratokat szinte lehetetlen Magyarországon kívül beszerezni.

A tervet mindezek miatt a SOE vezetősége ellenezte. További aggodalomra adott okot, hogy Bougheynak semmiféle harctéri-gyakorlati tapasztalata nem volt, viszont annál többet tudott a SOE tevékenységéröl, kiváltképp a jugoszláviai műveletekről. Így fogságba kerülése esetén komoly kockázatot jelentett. A figyelmeztetések ellenére Boughey, aki már jó ideje a londoni föhadiszállás egyik íróasztala mögött ült, hajthatatlan volt. A kapkodva összeállított akció az elejétől fogva kudarcra volt ítélve. A múvelethez még két SOE ügynök csatlakozott. A rádiós az 1916-ban Brazíliában született Anthony Samuel Manley őrmester volt, a tolmács pedig a magyar származású Alexander Vincent hadnagy (4. ábra).

Vincent valódi neve Vass Francis Alexander volt, aki Vas Sándor néven 1912. október 26-án született a Heves-megyei Kömlőn. Néhány évvel később a család Kanadába emigrált, ahol az ontarioi Wellandban telepedtek le. Szedőgép kezelőként dolgozott Torontóban, amikor 1943 elején besorozták a Kanadai Hadsereg Egészségügyi Alakulatához. Néhány hónappal később a SOE önkénteseket toborzott magyarországi bevetésekhez. Mivel már folyékonyan beszélt angolul is, jelentkezett a felhívásra, amit elfogadtak, így 1943 októberében leszerelték a Kanadai Hadseregböl. A Skóciában zajlott kiképzés során elöljárói jellemzése szerint magas erkölcsi normákkal rendelkező, a szövetségesekhez fenntartás nélkül lojális katona volt, aki a teljes programot kiváló eredménnyel teljesítette és a legjobb rádió operátorok egyike lett. Mindemellett a Ringwayben tartott ejtőernyős kiképzésen is a legkiválóbbak közé tartozott. Tulajdonképpen egy véletlen folytán került Boughey csapatába, ugyanis az eredeti tag az ugyancsak magyar származású Steve Mate, (fedőnevén Steven Maitland) aki 1911. augusztus 20án született Tolnán, 1944. április 17-én egy légi szerencsétlenség következtében életét vesztette Anglia partjainál, miközben épp Boughey-hoz tartott, hogy csatlakozzon a bevetéshez. Így helyette Vasst jelölték ki a csapat tolmácsának.

Boughey, hogy valódi kiléte rejtve maradjon, hamis és visszadátumozott iratokkal a Black Watch nevü skót ezred őrmestereként vett részt a bevetésen John Connor álnéven, a csoport parancsnoka pedig „névleg” Wright őrnagy lett. A bevetést 1944. július 3-4-ének éjjelére tűzték ki, a négy ügynök célba juttatására pedig a 148. század egyik Halifax gépét jelölték ki, Bird őrnaggyal és legénységével.

\section{A legénység}

A 148. század 1944. január 4-én kapta meg legújabb feladatkörét. Philip Victor Bird őrnagy 24 éves kora ellenére a RAF veteránjának számított, rendkívül tapasztalt és képzett pilóta volt (5. ábra). Korábban a 614 . század kötelékében repült, úgynevezett „nyomkereső” (pathfinder) bevetéseken, amelyre csak a legtapasztaltabb pilótákat és legénységet választották ki. Bird már teljesített egy szolgálati időszakot, amely után vissza is vonulhatott volna az aktív szolgálattól, ehelyett azonban egy újabb szolgálati időszakra jelentkezett. Sajnos 


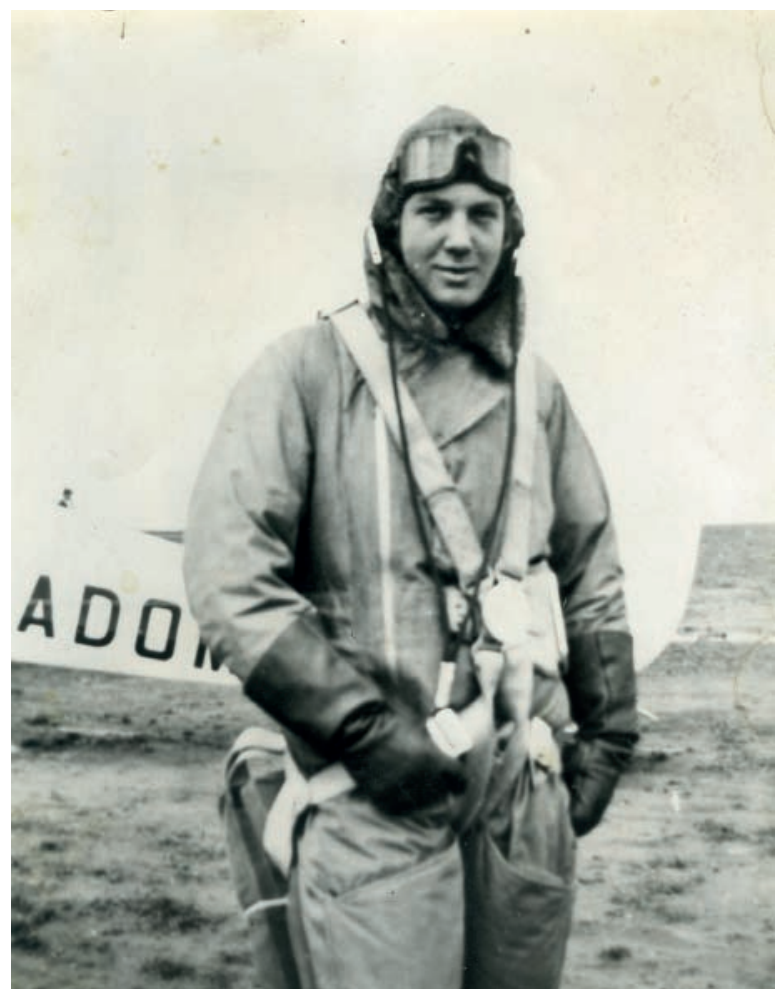

5. ábra. A gép pilótája, Surry Philip Victor Bird örnagy. A kép 1935-ben készült a pilótaiskolán közvetlenül az első egyedül repülése után. (Forrás: Penelope Bird Barnard)

a kevés elérhető dokumentum miatt nem lehet pontosan nyomon követni pályafutását, annyi azonban biztos, hogy 1943. szeptember 23-án Angliába visszatérve Halifax típusátképzésen vett részt, amellyel egy időben a „nyomkereső” kurzust is elvégezte. A 148. század Hadműveleti naplója szerint 1944. június 19-én érkezett meg a századhoz, ahol a 'B' raj parancsnokává nevezték ki. Mivel a század parancsnokának Brotherton-Ratcliffe őrnagynak szolgálati megbízatása lejárt, így június 25-én Bird őrnagy lett a század új parancsnoka (6. ábra).

Legénységének csupán 24 repült óra hiányzott szolgálati idejük teljesítéséjez és Bird minden erejével azon volt, hogy ezt mielőbb teljesíthessék. Sajnos róluk nem sokat tudni.

A francia Tilmont Marcel nem tartozott az eredeti legénységhez. Valószínű a háború elején menekült Angliába, majd később a RAF kötelékében, de továbbra is a Szabad Francia Légierő katonájaként harcolt tovább hazájának megszállói ellen. Szerencsétlenségére azon az éjszakán plusz tagként jelölték ki Bird gépére, mint a rakomány kidobásáért felelős személyt. Ennek oka az lehetett, hogy a legénységnek még nem sok tapasztalata volt az ellátmányok ledobásában, viszont Tilmont addigra már 20-30 bevetést tudhatott a háta mögött, így jártasságára igen nagy szükség volt.

Arthur Archer Lee rádiós / lövész szintén 1944. június 19-én érkezett a 148. századhoz (7. ábra). Testvére, Alan Lee - aki szintén a RAF kötelékében szolgált - így írt a testvéréről:

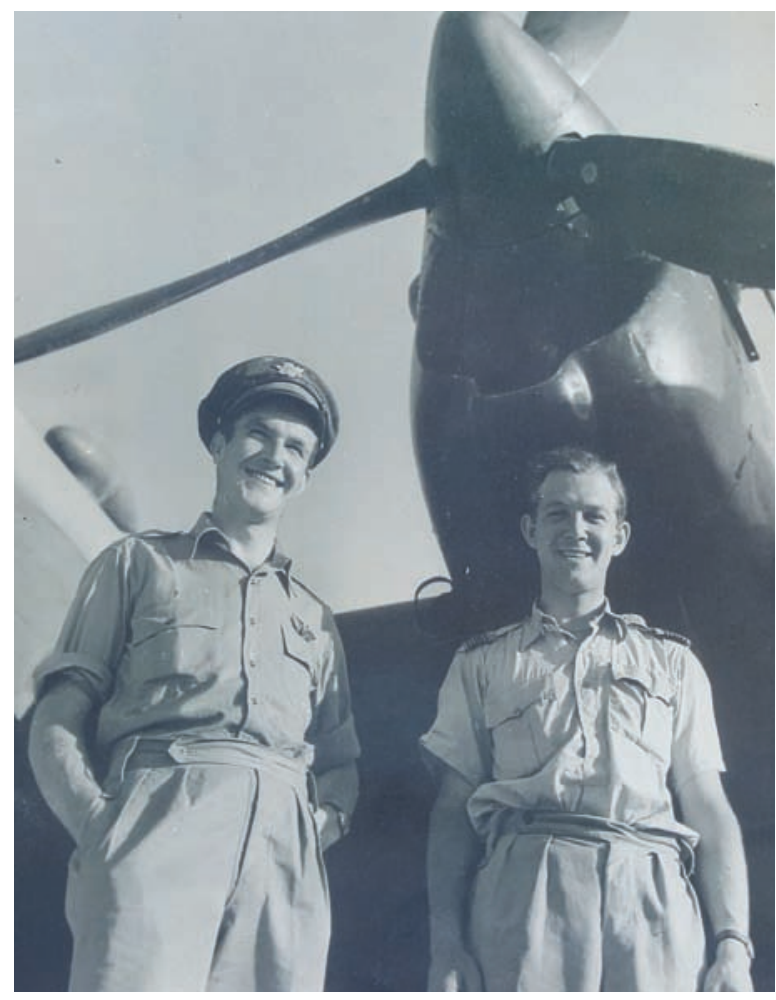

6. ábra. A 148. század egyik Halifax gépe elött. Jobbra Bird őrnagy. (Forrás: Penelope Bird Barnard).

„A bátyám 1909-ben született Notthinghamben. A család 1910-ben Ausztráliába költözött és 1924-ig éltek ott majd visszatértek Angliába. Arthur a rádiós kiképzést Blackpoolban és Yatesburyben kapta, a lövész kiképzést pedig Stormy Downban. Ezután Pockalingtonba vezényelték a Hadmüveleti Kiképző Egységhez.

Amikor Olaszországban szolgált egy bevetés során kényszerleszállást kellett végrehajtaniuk az észak-afrikai sivatagban. Amíg ki nem mentették őket, 2 napon át csupán árpacukron, malátás tejen és egy kulacs vízen éltek.

Azt tudom, hogy Bird örnagy, a Halifax parancsnoka, aki szintén Notthinghamből származott, J. Shipstone unokaöccse volt, aki akkoriban Notthingham legnagyobb sörfőzdéjének tulajdonosa volt."

A kanadai Donald David Charles Stewart navigátor 1941. július 9-én csatlakozott az RCAF (Királyi Kanadai Légierő) kötelékéhez és az évek során számos egységben szolgált (8. ábra). 1944. április 12-én érkezett meg a 148. századhoz.

1944. július 3-ának éjjelén a tervek szerint 4 Halifax indult olaszországi célpontok felé, 3 Halifax Jugoszlávia, 7 Halifax Lengyelország és 1 Lysander Görögország felé. A dátum a legnagyobb tragédiával végződött bevetésként vonult be a század krónikájába, az egész egység fennállása óta. A tizenöt útnak indult gépből négyet lelőttek.

Már a bevetés előtti eligazítás is vitába torkollott, ugyanis Bird őrnagy úgy határozott, hogy a gépeknek együtt, zárt alakzatban kell repülniük Bukarest körze- 


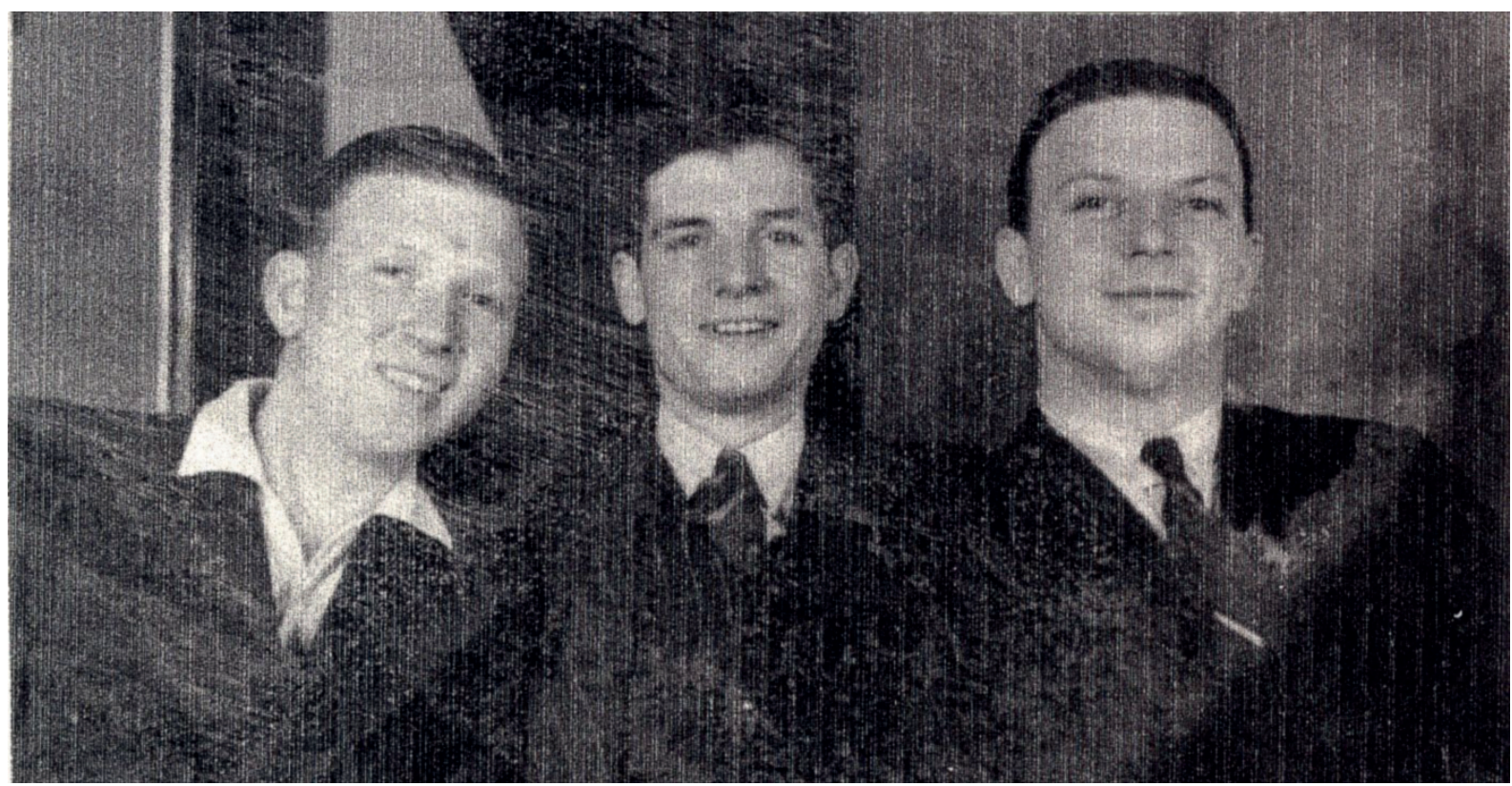

7. ábra. A gép rádiós/lövésze, Arthur Archer Lee törzsörmester (jobb szélen), egy családi fotón. (Forrás: Lee családja).

téig, majd ott szétválva mindenki a számára kijelölt ledobási pont felé veszi az irányt (9. ábra). Jack Pogson tiszthelyettes aznap a JP254/FS-D jelü Halifax parancsnokaként lengyelországi célpontot kapott feladatul. 42 bevetéssel a háta mögött rossz előérzete volt, ugyanis a többgépes alakzatot bombázó kötelékként azonosíthatják, amivel magukra vonhatják a légvédelem figyelmét. Így hát felszállás után szavazásra bocsátotta a kérdést a legénység között, akik egyhangúan parancsnokuk mellé álltak, így az utasítást megszegve kiváltak az alakzatból és egyedül folytatták útjukat. Mint később kiderült ők voltak az egyetlenek, akik sikerrel teljesítették a feladatukat és épségben vissza is tértek. ${ }^{2}$

A SAVANNA 101 / DEERHURST kettős fedőnevü bevetésre Bird őrnagyot a század (10. ábra) parancsnokát és legénységét jelölték ki. A parancs szerint Boughey csoportjának célba juttatása mellett, nagy mennyiségü ellátmányt is le kellett dobniuk Szerbia területén a Basil Davidson által támogatott partizánoknak. Ennek fedőneve SAVANNA 101 volt.

A JP286 szériaszámú FS-S „Sugar” kódjelü Halifax Mk II, július 3-án este 21.11-kor hagyta el Brindisi repterét és soha többé nem tért vissza. Senki sem maradt, aki útjukról mesélhetett volna, így a dokumentumok és a logikus következtetések alapján csak felvázolni lehet a történteket (11. ábra).

\section{Az utolsó bevetés}

A legénységnek valószínü az odavezető úton kellett volna ledobni az ellátmányt, de feltehetően a ledobási pontnál vagy nem kaptak visszajelzést a földről

2 Terry Maker 2009: Missing - Believed Killed https://www. bataheritagecentre.org.uk/wp-content/uploads/2016/03/MissingBelieved-Killed.pdf vagy az időjárás nem tette ezt lehetővé, így folytatták útjukat második célpontjuk felé. Valamivel éjfél után a Balatontól északra elérték a négy ügynök számára kijelölt pontot, majd azok szótlanul elhagyták a repülögépet. Bird őrnagy ezután hazafelé vette az irányt.

Azon az éjszakán a Luftwaffe Szombathelyen állomásozó NJG6 III. századának Me-110-G4-es éjszakai vadászai kutatták az eget. Éjjel 01 óra 50-kor - berlini idő - a földi radarállomások segítségével és fedélzeti radarjával Leopold Fellerer százados a század parancsnoka, jelentése szerint Kaposvártól 10 km-re északkeletre (ami igen pontatlan meghatározás) egy 1700 méteren repülő Halifaxot vett célba és tüzet nyitott. A négymotoros bombázó a találatok következtében kigyulladt és lezuhant. Ez volt Fellerer 34. légigyőzelme. Hogy mi történt valójában azon az éjszakán, arról részletes képet adnak a 2016-ban újraindított kutatásunk során megkérdezett szemtanúk. Sági Ferencné, Takács Mária, 93 éves hetesi lakos, így idézte fel az eseményt:

„Azon az éjszakán a házunk verandáján voltunk. Gyönyörü holdvilágos éj volt, szinte felhőtlen égbolt. Egyszer csak mély morajlásra lettünk figyelmesek. Egy nagy repülögép közeledett körülbelül Székesfehérvár felöl. Nagyon alacsonyan jött. Sokkal alacsonyabban, mint azok az amerikai gépek, amik nappal bombáztak minket. A repülö mögött jött egy kis vadászgép, ami úgy negyed akkora lehetett. Egyre csak üzte ezt a nagy gépet. Hol föléje került, hol alája, hol megelözte, hol lemaradt. Ez egy magyar gép volt [téves visszaemlékezés, valójában német gép volt] és a pilótája nagyon ügyes volt. Sokáig még tudtuk is a nevét de már nem emlékszem rá. Egyszer csak azt vettük észre, hogy a nagy gépből lángok csapnak ki. Láttuk, hogy meredeken ereszkedni kezd Mezőcsokonya irányába, majd hallottuk, ahogy a földnek ütközéskor felrobbant. Azonnal futni kezdtünk a 


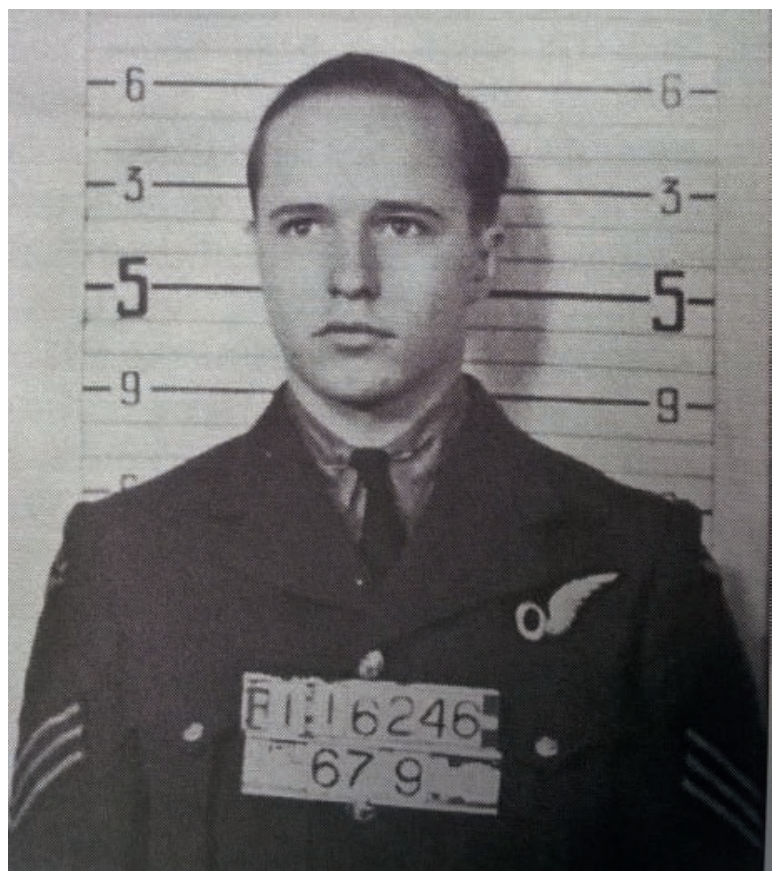

8. ábra. A gép kanadai navigátora, Donald David Charles Stewart. Hazájában tiszteletére ma a Stewart Lake nevü tó viseli a nevét. (Forrás: Oliver Clutton-Brock).

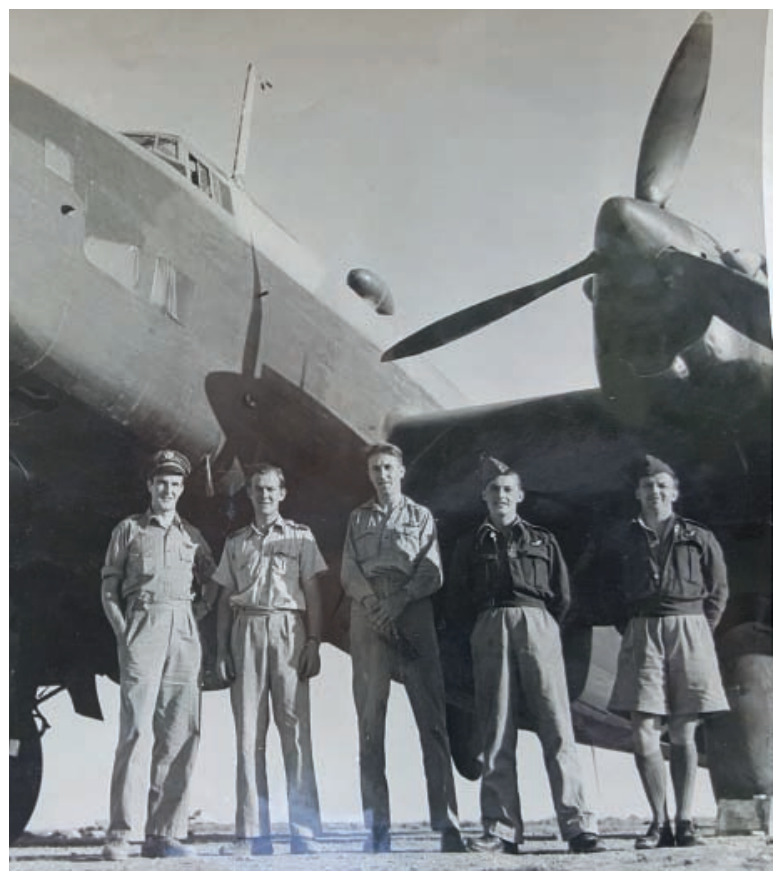

9. ábra. A 148. század egyik Halifax gépe előtt. Bird örnagy balról a második. (Forrás: Penelope Bird Barnard).

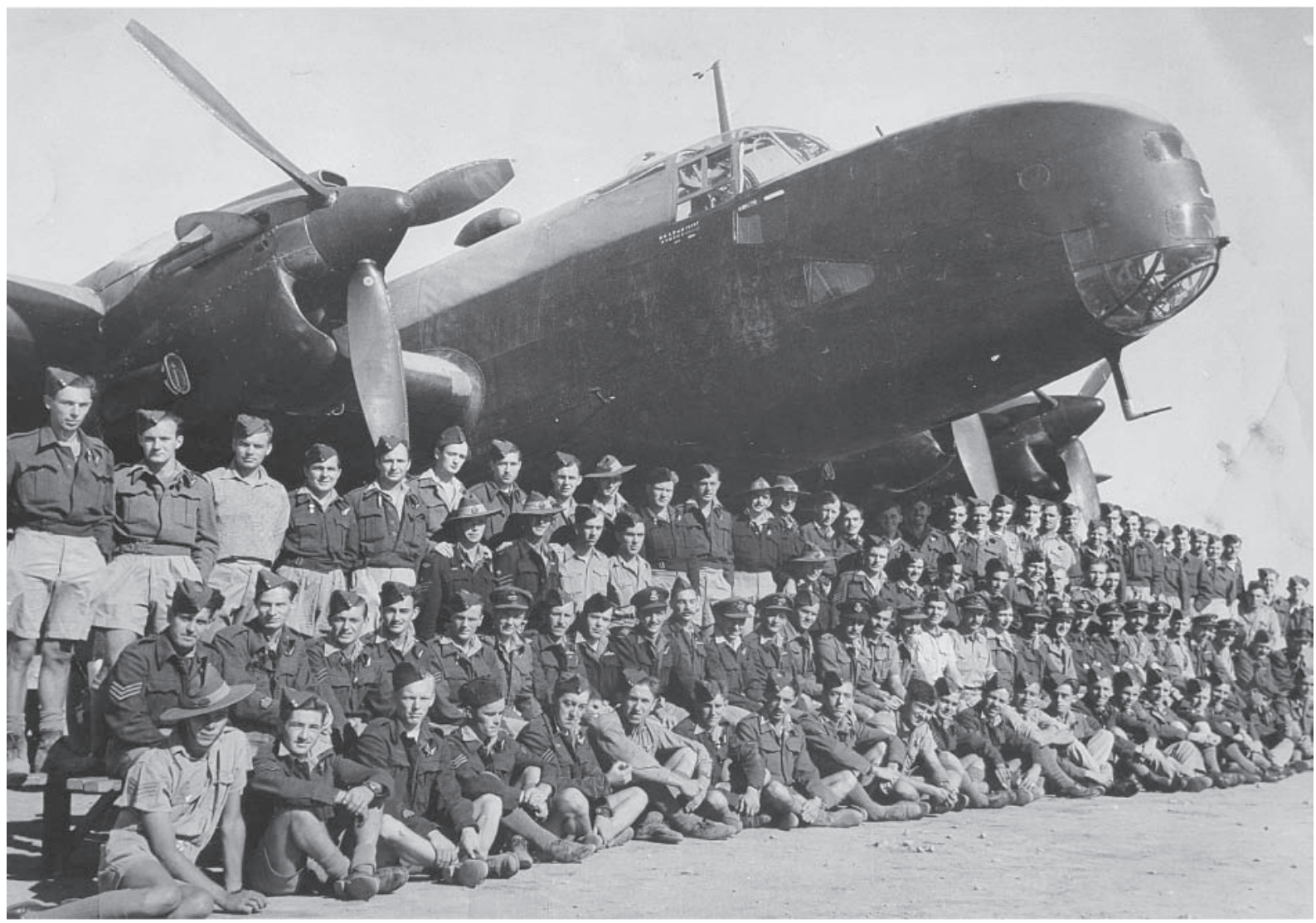

10. ábra. A 148. század csoportképe. Alulról a második sorban középen, világos egyenruhában Bird őrnagy. (Forrás: Penelope Bird Barnard). 


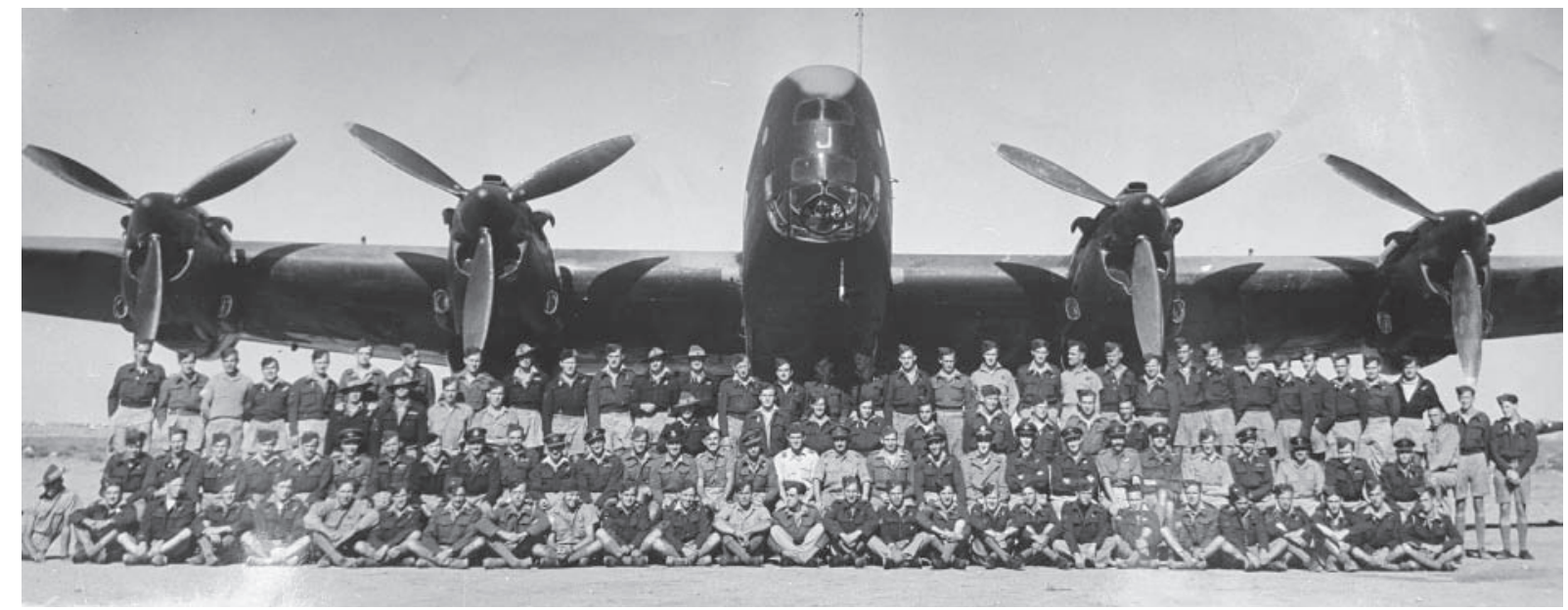

11. ábra. A 148. század csoportképe, háttérben az FS-J jelü Halifax. Alulról a második sorban középen világos egyenruhában Bird örnagy. (Forrás: Penelope Bird Barnard).

helyszínre. Ahogy odaértünk láttuk, hogy a gép elöször nekiment a nyárfasornak, majd a mögötte elterülö rozsföldre esett. Ezen aztán végigcsúszott, úgy 100 méteren át egészen a nyíresi szőlőtőkék közé. Az elsők között voltam, aki odaért. Sok helyen még füstölgött a roncs. Láttam a halottakat is. Nem volt mindegyikük megégve. Makulátlan, ápolt úriemberek voltak. Egyikük távolabb feküdt a roncsoktól, ő valószínüleg az ütközéskor kirepült. Mire odaértünk, már volt ott egy férfi. Észrevette, hogy a távolabb heverö repülös ujján egy arany jegygyürü van. Ezt azonnal lehúzta és elrakta. A roncsok között rengeteg élelmiszer és ruhanemü volt. Édesapám felvett egy nagy csomag összekötözött posztót. Világos khaki színü volt és a becsapódástól apró lyukak voltak rajta, de még használható volt. A szüleim ebböl varrtak nekünk nadrágot, inget, kabátot. Apám félve vitte el, mert a közben kiérkező csendőrök, gyanakvó szemmel néztek. Időközben megérkeztek a fináncok is, akik azonnal lefoglalták az élelmiszert és a ruhanemüt.

Mi nem sajnáltuk a repülősöket, mert az ellenségeink voltak. Nyírespusztán temették el őket. A temetőben ástak egy gödröt, az aljára szalmát szórtak. Erre tették a halottakat, majd betemették a gödröt. Fejfájuk nem volt, csak egy jelzés, hogy tudni lehessen, hol van a sír."

Csapó Sándor, egykori hetesi lakos, 83 éves:

„Tíz éves voltam. A robbanást nem halottuk, csak másnap mondták, hogy mi történt. Reggel, már mentünk is biciklivel, hogy megnézzük. Hetes déli végénél lévő földútról kerekeztünk a József major irányába. József majortól délnek volt Pat puszta, vagy pati erdő. A major és a puszta között volt egy hatalmas nyárfasor, amik közel 20 méter magasak voltak. A repülő Hetes felöl jött és voltak, akik látták, ahogy égett a levegőben. A gép nekirepült a nyárfáknak és a fasor után elterülö területre esett, majd ezen csúszva a nyíresi szőlőhegy irányába a tőkék közé rohant, ahol volt egy akácos. Ennek ment neki. A roncsok nagy területen szóródtak szét. Én a halottakat nem láttam. Mire odaértünk már ott voltak a csendőrök és éberen figyeltek, így nem lehetett sokat nézelődni. Én megláttam a földön egy érdekes tárgyat, ami körülbelül akkora volt, hogy egy gyufásdobozban elfért volna. Nem tudom mi volt az. Felvettem és magammal vittem, otthon pedig eldugtam. Csak hónapokkal később vettem elő. Láttam, hogy az egyik végéből valami por potyog ki. Többször rácsaptam, mire ez a por elkezdett sisteregni. Akkor aztán egy vasdarabbal ütöttem rá, mire az felrobbant a kezemben. A bal kezem két ujja leszakadt, a jobb combom pedig tele ment szilánkkal. Többsége még ma is benne van. A mellettem álló testvérem mindkét szemöldöke és az arca is tele ment szilánkkal. Rajtam kívül is voltak még páran, akik szerencsétlenül jártak."

Fisi Lajos, 85 éves mezőcsokonyai lakos:

„13 éves voltam. Éjjel hallottuk a robbanást, másnap reggel kimentünk megnézni mi történt. Nem láttam közelröl a roncsokat, mert a szüleim nem engedtek oda. A gép a szölös-gyümölcsösre esett. A halottakat egy helybéli, Hegedüs József temette el többed magával. Ez önkéntes alapon zajlott. Amikor a háború után az angolok eljöttek a halottakért, akkor is Hegedüs segített nekik megmutatta, hogy hova temette el őket és mindenben segített nekik. Viszonzásul felajánlották neki, hogy ha disszidálni akar, akkor segítenek neki kijutni az országból. Ez végül nem volt lehetséges, mert addigra már mindenütt ott voltak a szovjet katonák. Hegedüs végül pár évvel később az USA-ba emigrált."

\section{Rosszkor, rossz helyen}

A négy ügynöknek a Balatontól északra kijelölt ponton kellett volna földet érnie, ahol az előre megbeszéltek szerint várták őket. Ehelyett azonban egy sikertelen rárepülés után végül kilométerekre a kijelölt ponttól ugrottak ki és szerencsétlenségükre a herendi porcelángyár közelében fekvő zsidó munkatábor szomszédságában egy erdő kellös közepén landoltak. A csapat két részre szakadt, egyik fele a hegy egyik oldalán, másik fele a másikon. Boughey alezredes később így emlékezett vissza a történtekre: 
„Az ejtőernyőink fennakadtak a fákon, én 30 láb magasan lógtam a hevedereken...

Esélyünk sem volt elrejtőzni. Pirkadatkor a Civil Gárda vezetésével már ott nyüzsgött a Magyar Hadsereg. Ennek ellenére Vincentnek és nekem (Vincent a hegy ugyanazon oldalán ért földet ahol én) közel 24 órán át sikerült elrejtőznünk. Sokszor csak néhány lábnyira haladtak el mellettünk az erdőt csatárláncban kutató katonák. Az egyik átfésülés alkalmával azonban az egyik katona pont a rejtekhelyünk felett haladt át. Szerencsénk volt, hogy ijedtségében nem lőtt le minket! Elfogtak és levittek az erdőben felállitott föhadiszállásra, ahol a többiek már ott voltak.

Itt meztelenre vetkőztettek, átkutatták a felszerelésünket, kihallgattak, majd egy teherautón Veszprémbe vittek ahol közölték, hogy másnap mindegyikünket agyon fognak löni! Ehelyett azonban vonattal a titkosrendőrség föhadiszállására vittek Budapestre, ahol több napon át tartott a kihallgatásunk. Ezután közölték, hogy a nemrégiben hatalomra került Nyilaskeresztes Kormány átad minket a német hatóságoknak további kihallgatások céljából, amelyre Budán a Gestapo föhadiszállásán fog sor kerülni. Így nem sokkal később átszállítottak minket a folyó partján fekvő hírhedt Fő utcai börtönbe.

Augusztusban és szeptember nagy részében több alkalommal is kihallgatott a Gestapo... Októberben, az oroszok közeledtével, vonaton több zsidóval együtt átszállítottak minket Bécsbe, a hírhedt elizabetstrassei börtönbe. Itt különválasztottak és úgy tünt, hogy sok más nemzetiségü és jogállású fogollyal együtt minket is likvidálni fognak - ami mindennapos esemény volt a börtönben. Néhány nap múlva azonban együtt újra vonatra raktak, de fogalmunk sem volt, hogy hova szállítanak csak annyit tudtunk, hogy nyugatra. Végül kiderült, hogy az úti cél a Frankfurt-am-Main közelében lévő Ober Ursel, a Luftwaffe kihallgató központja. A kihallgatások nem voltak túl komolyak és pár nappal később átvittek minket Wetzlarba a Luftwaffe elosztó központjába... A Gestapo nyomatékosan a tudtunkra adta, hogy vissza fognak hozatni hozzájuk, de a Luftwaffe ezt nem hagyta jóvá tekintve, hogy hadifoglyok voltunk igy az elosztó központjukba szállíttattak minket. Mivel a szárazföldi hadsereg egyenruháját viseltük, itt átadtak minket a Wehrmacht Limburg közelében lévő elosztó központjának. Itt történt, hogy a RAF egyik bombázása során, amely a mellékvágányokat érte, szerencsétlen módon találatot kapott a hadifogolytábor tiszti részlege is, aminek következtében Wright örnagy és Vincent hadnagy életüket vesztették."3

Boughey valódi kilétét sosem tudták meg a németek. Ő és Manley kitünően ismerték a süketnéma jelnyelvet, így számítva a kihallgatásokra fedőtörténetet találtak ki, amelyet kézjelekkel kommunikálva egyeztettek. ${ }^{4} \mathrm{~A}$ trükk bevált. A Boughey által ismertetett „kalandok” végállomásaként a négy ügynök Limburgba, a Stalag XIIA hadifogolytáborba került. Sajnos azonban közülük ketten már nem érhették meg a háború végét.

3 John Grehan and Martin Mace 2012: Unearthing Churchill's secret army - The official list of SOE casualties and their stories 4 Manley unokahuga, Jane Starkie visszaemlékezése
1944. december 23-án az Egyesült Államok 9. légiereje támadást intézett a limburgi vasúti rendezőpályaudvar ellen. A támadást éjszaka a RAF gépei folytatták, ám véletlenül néhány célmegjelölő világítóbomba a hadifogolytábor területére esett. A tábort ezt követően több bombatalálat is érte, aminek során Wright őrnagy és Vincent (Vass) Alexander hadnagy is életüket vesztették.

A tábort végül a Vörös Hadsereg szabadította fel. Boughey felfedte valódi kilétét a szovjet parancsnokok előtt, akik Odesszán keresztül visszajuttatták Angliába.

\section{Kutatás a helyszínen}

Az 1997-ben megkezdett kutatásom sajnos különböző okok miatt félbeszakadt. Az évek során leginkább levelezés útján próbáltam dokumentumokhoz jutni és kapcsolatokat kiépíteni. Az összegyűlt adatokból lassan összeállt a történet, de maradt még jó pár megválaszolatlan kérdés, amire szerettem volna választ kapni. Egyrészt jó lett volna még több szemtanút meghallgatni, másrészt még mindig titok övezte a gép becsapódásának pontos helyét. Így 2016 augusztusában ismét ellátogattam Mezőcsokonyára. Derner Tamás barátommal és kutató társammal már a legelső alkalommal sikerült egy újabb szemtanút megszólaltatnunk, Fisi Lajos személyében. Filó Ferenc, akivel még 1997-ben találkoztam sajnos időközben eltávozott, én pedig nem találtam vissza arra a helyre, amit akkoriban mutatott. Ezért Lajos bácsit kértük meg, hogy mutassa meg. A terepre érve azonban jól láthatóan bizonytalan volt és nem tudta megmondani, hogy hol feküdt a roncs. Mint kiderült, az igazi problémáink itt kezdődtek, aminek megoldása közel másfél évet váratott magára.

$\mathrm{Az}$ augusztusban és szeptemberben tett látogatásaink során sikerült két újabb szemtanút találnunk. A hetesi Takács Máriának igen részletes emlékei voltak és mint később kiderült, ezek hajszálpontosnak bizonyultak. Csapó Sándor egykori hetesi lakossal pedig a terepen, térképek segítségével próbáltuk beazonosítani a helyszínt. De a próbálkozásunk ismét kudarcba fulladt. Habár az eseményre élénken emlékezett, a helyszínen nem tudta betájolni magát. Ennek magyarázatát a nálunk lévő két térkép szolgáltatta. Egyik a mai tájat ábrázolta, a másik pedig egy 1963-as légifelvétel volt, amelyről feltételeztük, hogy nem sokban térhetett el az 1944-es állapotoktól. A két térképet egymás mellé helyezve azonnal megértettük a szemtanúk bizonytalanságát. Ahol 1944-ben még nyüzsgő élet folyt, gazdaságokkal, cselédszállásokkal, szeszfőzdével, csárdával és a gazdálkodáshoz szükséges építményekkel, ma csak szántó és erdő van. Az egykori épületeknek, szőlősnek, gyümölcsösnek, nyárfasornak már nyoma sincs. Nem csoda, hogy a tájékozódási pontok eltűnésével egyikőjük sem ismerte ki magát a tájon. Így hát megpróbáltuk a visszaemlékezéseiket „rávetíteni” az 1963-as légifelvételre, majd onnan a jelenlegi domborzati fotóra. Ezután már „csak” át kellett fésülni a lehetséges helyeket. Természetesen nagyobb darabokra nem lehetett számítani, hisz 
az esetet követő napokban a roncsokat elszállította a katonaság, majd a következő hét évtized talajmüvelése tovább csökkenthette a maradványok számát. Ami mégis megmaradhatott, azok csupán néhány négyzetcentiméteres darabok lehettek, amik jelzés értékkel bírnak az egykori helyszín beazonosításához.

A szükséges engedélyek beszerzése után 2019ben kezdtük meg a kutatást. Az első néhány sikertelen nap után rábukkantunk az első leletekre, pontosabban három tárgyra. Két, egyértelmüen repülőgépről származó lemez darabra és egy, feltehetően egy ejtőernyő lezáró csatjának réz peremére. Nagy reményekkel kutattunk tovább, azonban egyetlen további darabot sem találtunk dacára annak, hogy a leletek 200-250 méteres körzetét átfésültük.

Két további sikertelen nap után újabb leletekre bukkantunk és a nap végén már egyértelmű volt, hogy megtaláltuk azt a helyet, ahol a roncsok feküdtek. Meg-

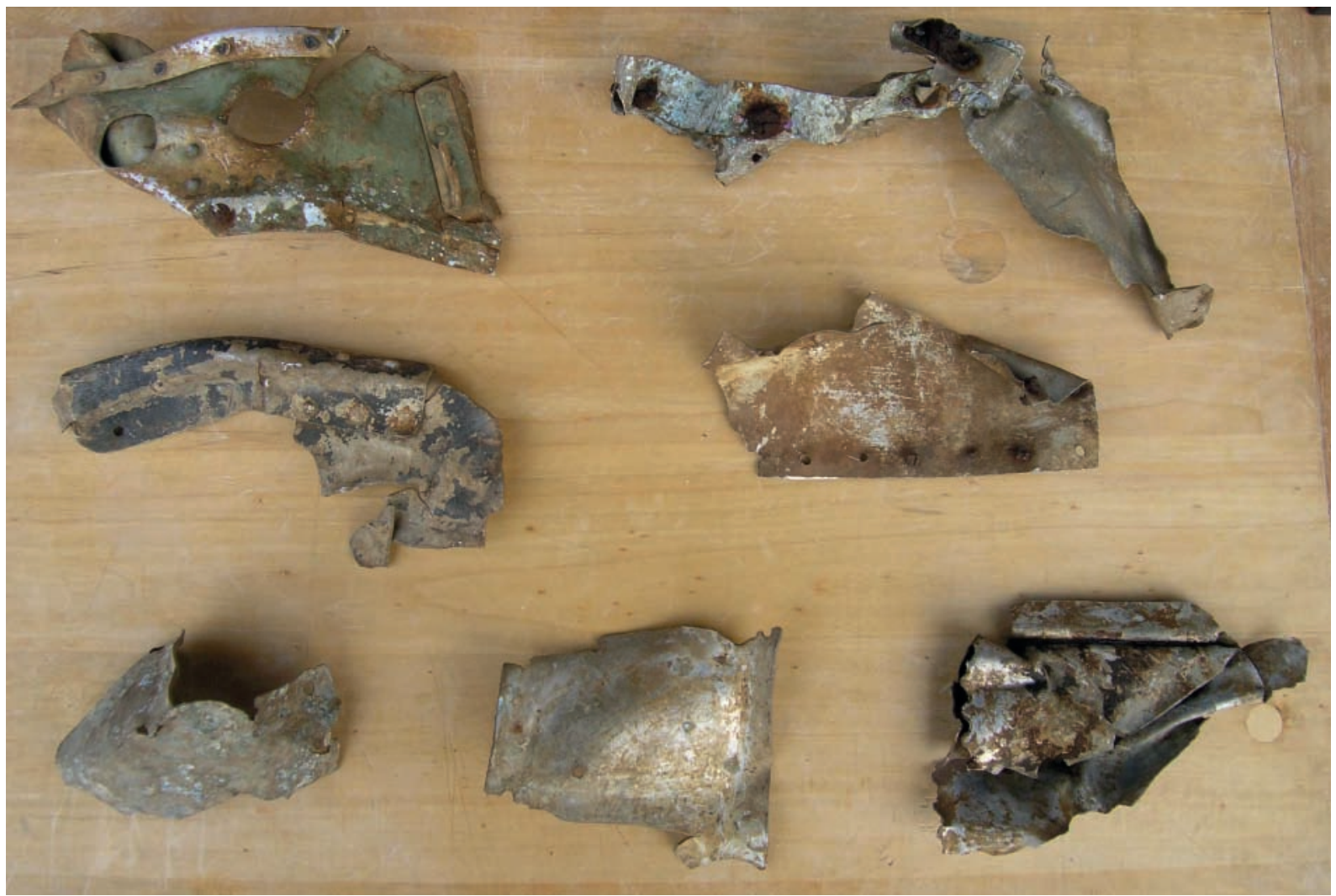

12. ábra. A 2019-2020-as felmérés során elökerült több száz roncsdarab közül néhány. Az utólagos átvizsgáláskor sok alkatrész sikerült beazonosítanunk és eredeti helyét és rendeltetését megállapítanunk.

(Fotó: Nagy Gábor).
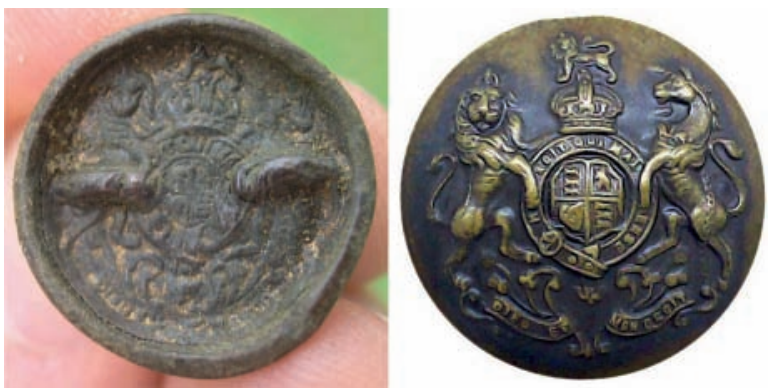

13. ábra. Balra az egyetlen elökerült személyes tárgy, egy brit katonai zubbonygomb. Jobbra egy eredeti példány. Az eredetileg domború gomb, teljesen összepréselödött. (Fotó: Nagy Gábor).

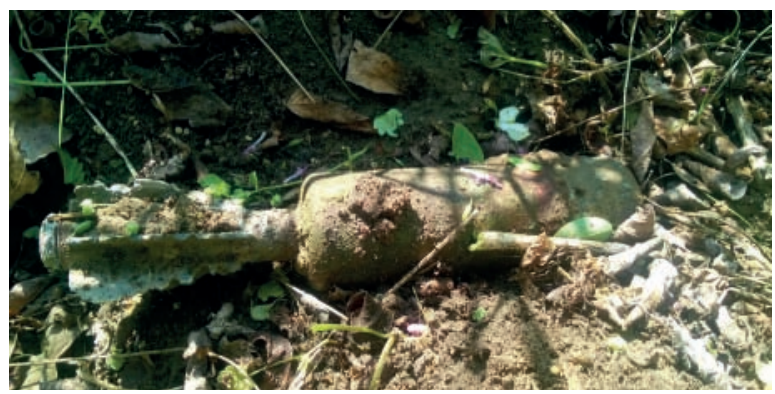

14. ábra. Ez az angol 2 hüvelykes aknavető gránát a gép rakományához tartozott. Feltételezhetően a Basil Davidson partizánjainak szánt ellátmány része volt. A területen több ilyen aknavető gránát szétrobbant darabját találtuk meg, amely magyarázatot adott a szemtanúk által leírt több kisebb utórobbanásra. A lövedéket a bejelentésünk utáni nap a tüzszerészek elszállították. (Fotó: Nagy Gábor). 
kerestük a roncsmező szélső határait, amelyek GPS pontjait bemértem, azokat felvittem a Google Earth térképére majd az 1963-as légifelvételre. Az így kapott adatok egyszeriben több kérdésre és rejtélyre is választ adtak (12., 13. és 14. ábra).

A gép utolsó másodpercei azonnal kivehetőek voltak, a szemtanúk beszámolóival összevetve pedig szinte megelevenedett. A legelső leleteink és a fő roncsmező közötti távolság 580 méter volt. A fö roncsmező egy koncentrált, megközelítőleg $80 \times 200$ méteres terület, ami azt jelenti, hogy a gép egyben ért földet. A legelső pont, ahol csupán három leletet találtunk azt a pontot jelölte, ahol a gép nekiment a nyárfáknak. A magas fák csúcsai igen hajlékonyak, így egy nagy sebességgel haladó repülőgépet nem tudnak a földre rántani, de az ütközés során nyilván néhány darabja levált. Ezt jól jelzi, hogy a két pont közötti 580 méteren semmit sem találtunk. A hely körülbelül megegyezik azzal, amit a szemtanúk az egykori nyárfasor pontjaként megjelöltek.

A fő roncsmező területe - az 1963-as légifotón nézve - részben egy szántón van, ami valószínűleg az egykori rozsföld területe, többsége pedig az egykori szőlős-gyümölcsös területén. A két területet elválasztó egykori akácfa sor és kerítés még ma is megvan. Természetesen a kerítés már nem, de a fasor fiatalabb egyedekkel igen. A legtöbb roncsdarabot ennek a fasornak a vonalában találtuk. Mindebből megállapítható volt, hogy a szemtanúk beszámolója teljesen pontos. A gép először nekirepült a nyárfáknak, tovább siklott majd a rozsföldön földet érve és azon csúszva nekirohant az azt határoló akácfa sornak, ahol átfordulva és darabokra szakadva szóródott szét a másik oldalon elterülő szőlős-gyümölcsös területén és elégett. De mit tett vajon Bird őrnagy az utolsó pillanatokban? Tényleg megpróbált kényszerleszállást végrehajtani, ahogy azt néhány szemtanú állította? A térkép elemzése erre is választ adott. A két pont közötti 580 méter távolságot és a 20 méter magas nyárfákat alapul véve kiszámítható, hogy a gép repülési szöge közel 2 fokos volt. Ez egy nagyon lapos pálya, ami megfelel egy leszálláshoz készülődő gép besiklási szögének. Ez minden kétséget kizáróan bizonyítja, hogy Bird megpróbált hasra szállni a géppel, ami részben sikerült is, azonban a sötétben feltehetően nem látta az előtte húzódó masszív fasort, amibe a nagy sebességgel csúszó gép belerohant (15., 16. és 17. ábra).

Európa térképére pillantva a gép útjára is választ kaptunk. Tudjuk, hogy a négy ügynök Herend térségében ugrott ki. Mivel Mezőcsokonya Herendtől délre fekszik, ez azt jelenti, hogy már visszafelé tartottak. A roncs körül rengeteg ellátmány hevert, ami azt jelzi, hogy a Davidson partizánjainak szánt utánpótlást nem dobták le. A kérdés az volt, hogy vajon Herend után megpróbálták-e újból célba juttatni, vagy egyből a brindisi bázis felé vették az irányt? Ha a térképen vonalat húzunk Herend és az olaszországi Brindisi között látható, hogy Hetes és Mezőcsokonya gyakorlatilag rajta fekszik az egyenesen. Az eltérés minimális, csupán néhány kilométer. Davidson partizánjai Novi Sad környékén tevékenykedtek, így ha megkísérelték volna újból ledobni a konténereket az útvonal jóval keletebbre haladt volna. Ezért biztonsággal kijelenthető, hogy amikor a támadás érte őket már hazafelé tartottak a bázisra.

Szintén a szemtanúk beszámolói és a dokumentumok összevetése adott választ arra is, hogy feltehetően Bird őrnagy lehetett az, akinek testét épségben találták meg. Takács Mária elmondása szerint egyikük holtteste a roncsoktól távolabb feküdt és nem volt megégve. Egy férfi, aki már előttük a helyszínre érkezett, ennek a repülősnek az újáról húzott le egy jegygyűrüt. A legénység tagjai közül csak az egyik lövész Kenneth Peter Mc Leod Cran főhadnagy és Philip Victor Bird őrnagy voltak nősek. Hogy kettőjük közül ki lehetett a kérdéses személy arra a fentiekben már idézett halotti anyakönyv bejegyzésében szereplő „többiek” szó szolgáltat bizonyítékot:

„...Egyik személyazonosságát megállapították: „Philip Victor vezető” Ennél Mária és szt. Domonkos érem volt. ĺgy feltehető, hogy katolikus volt. A többiek darabokra szakadtak és elégtek. ..."

\section{Múlt, jelen, jövő}

Bird őrnagy lányával, Penelope Bird Barnarddal már évek óta leveleztem és a 2016-2017-es 1 éves angliai kint tartózkodásunk jó alkalom volt rá, hogy végre személyesen is megismerjük egymást. A találkozóra 2017. május 14-én került sor Penelope Iondoni lakásán. 20 év után megpillanthattam a kis magyarországi falunál elesett fiatal és bátor pilóta fotóját. Ez a délután nagyon rövid volt ahhoz, hogy mindent átbeszéljünk, de az kiderült, hogy édesapja közel sem az átlagos pilóták közé tartozott:

„3 éves voltam, amikor édesapám meghalt. Én voltam a szeme fénye. Nem sokat volt otthon, végig szolgálatban volt. Sikerült megszereznem a repülési naplóját. Már a háború előtt is a légierőnél volt. Az Angliai Csatában, 1940-ben egy ellátó alakulatnál szolgált. Ha egy századnál pótolni kellett az elvesztett gépeket, ő repülte át őket a gyárakból. Ezenkívül berepülő pilóta is volt. Javitások, karbantartások után ő tesztelte a gépeket. Gyakorlatilag mindenen repült. Vadászgépeken, bombázókon, stb... Anyám mesélte, hogy egy alkalommal valamiféle autós túrán volt, amikor apám egy Wellington bombázóval arra repült és egy közeli mezőn leszállt. Felvette anyámat és repültek egyet. Apám később Észak Afrikába került valószínüleg a 336. századhoz, ahol Hurricane vadászgépeken repült. De ezen kívül valószínüleg több századnál is szolgált. Az afrikai évei alatt személyes naplót vezetett, naponta örökítette meg az átélt eseményeket. Elképesztő ezeket a sorokat olvasni. Apám remekül irt, szinte egy regény a naplója. Végigharcolta Máltát is, mindaddig, amíg a szigetet végleg meg nem tudták védeni. Iszonyatos harcok dúltak. Innen visszarendelték Angliába ahol azt hiszem idegkimerültséggel kezelték, amit ma posztraumatikus szindrómának hívnak. Van valahol egy fényképem, ahol apám egy repülőgép kabinjából kihajol és látszik, hogy a gépe orrán a nevem van: Penelope. 21 éves voltam, amikor anyám újból férjhez ment, de azt mondta, hogy apámat senki sem 


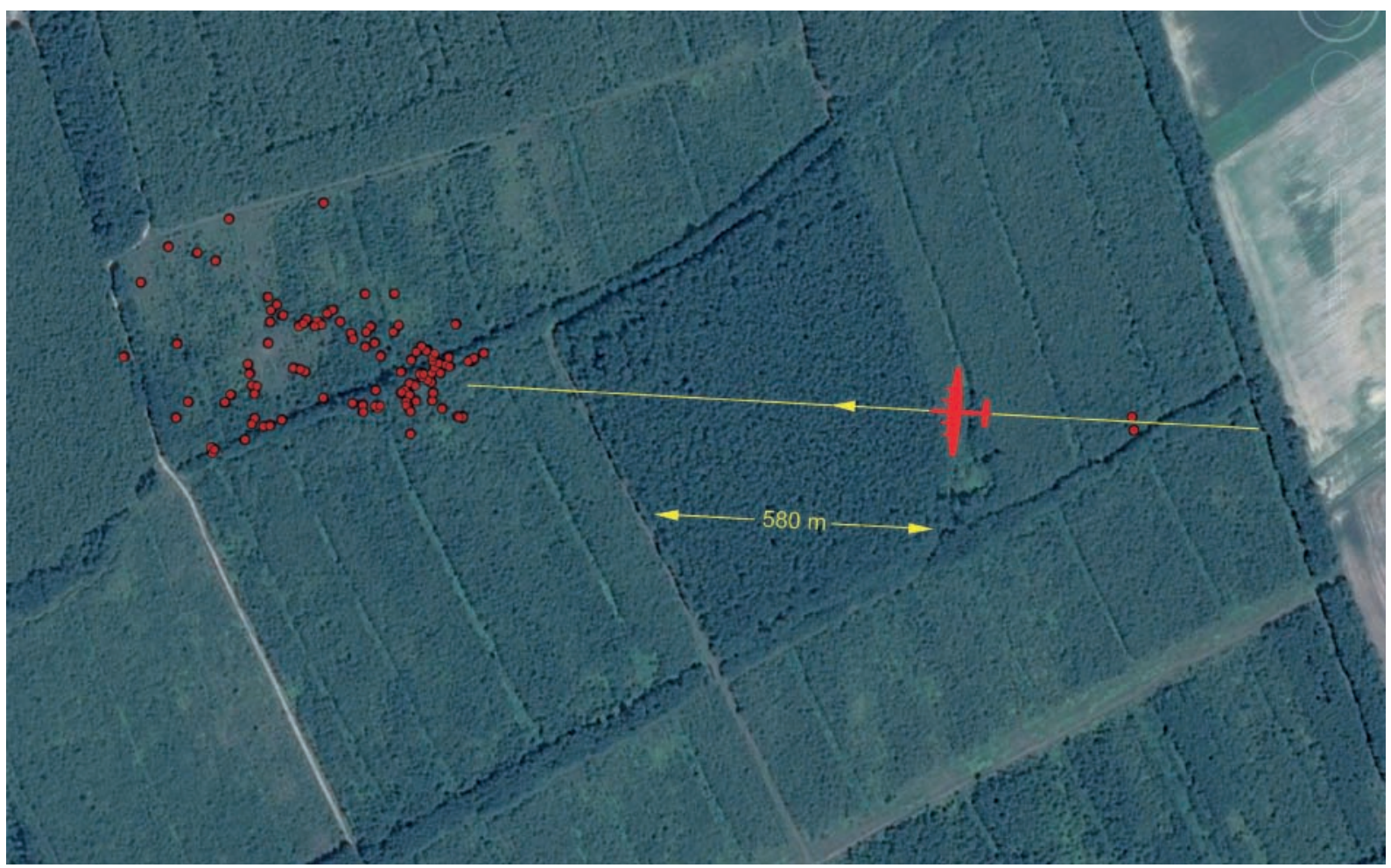

15. ábra. A roncsmező helye és a Halifax leszállási kísérletének nyomvonala egy mai légifotón ábrázolva. A jobb oldali két pont az egykori nyárfák helyét jelöli. (Forrás és ábrázolás: Google Earth és Nagy Gábor).

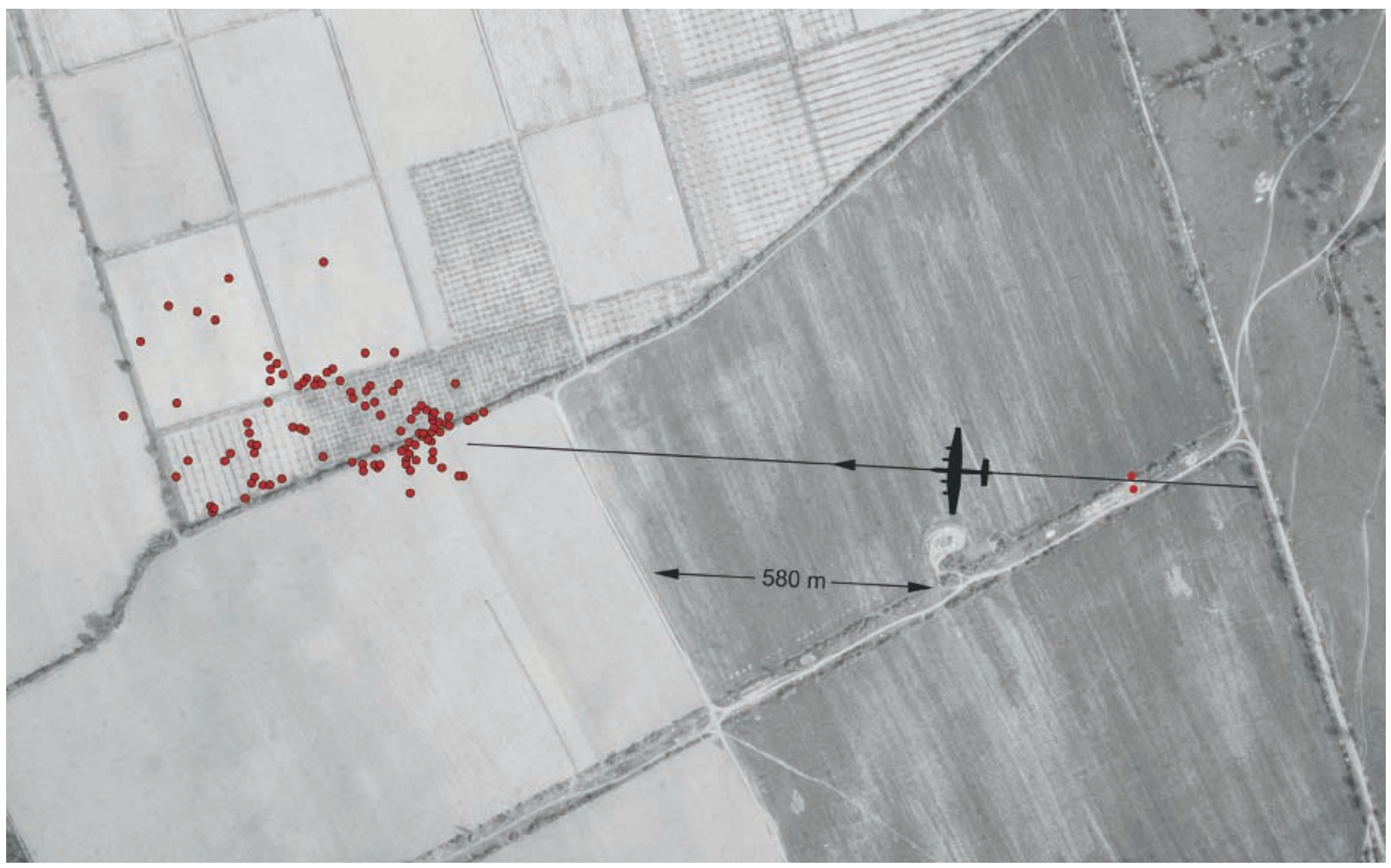

16. ábra. A roncsmező helye és a Halifax leszállási kísérletének nyomvonala egy 1963-as légifotón ábrázolva. A jobb oldali két pont az egykori nyárfák helyét jelöli. A fő roncsmező területén tisztán kivehető az egykori szölős-gyümölcsös és a fasor-kerítés, amely a rozsföldtöl elválasztotta.

(Forrás és ábrázolás: www.fentrol.hu és Nagy Gábor). 


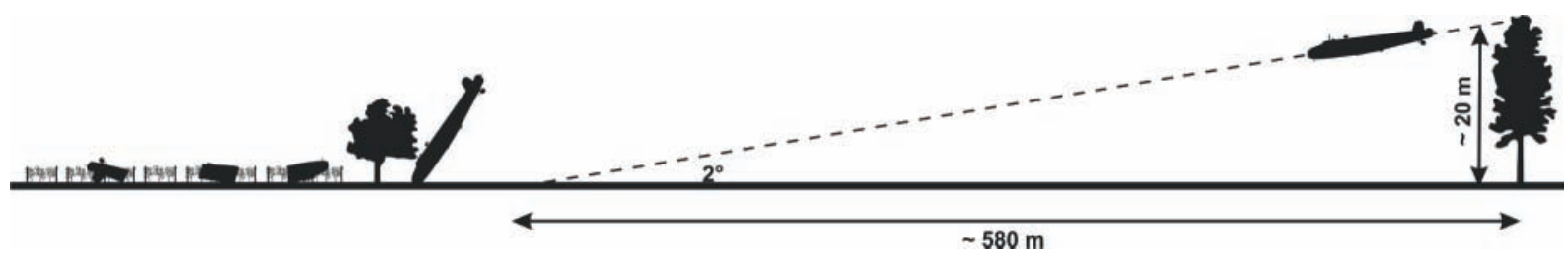

17. ábra. A Halifax leszállási kísérletének rekonstrukciója a feltárt roncsdarabok elhelyezkedése alapján. (Rajz: Nagy Gábor).

tudta pótolni. A szavaiból úgy éreztem, hogy nagyon karizmatikus egyéniség volt. Minden férfiban apám kedvességét, müveltségét kereste. Apám őszintén hitt abban, amiért harcolt. Hitte, hogy azt a borzalmat meg kell állítani. Úgy 14 éves lehettem, amikor anyámmal Olaszországba utaztunk. Egy gazdag máltai család hívott meg bennünket és a jachtjukon körutazásra vittek. Apám a máltai harcok alatt megmentette ennek a családnak az életét. Ezzel szerették volna megköszönni. Sajnos ennek részleteiröl semmit sem tudok. 15 évvel ezelőtt jártam Budapesten és meglátogattam a sírját. Jövőre nagyon szívesen ellátogatnék Mezőcsokonyára.” (18., 19. és 20. ábra).

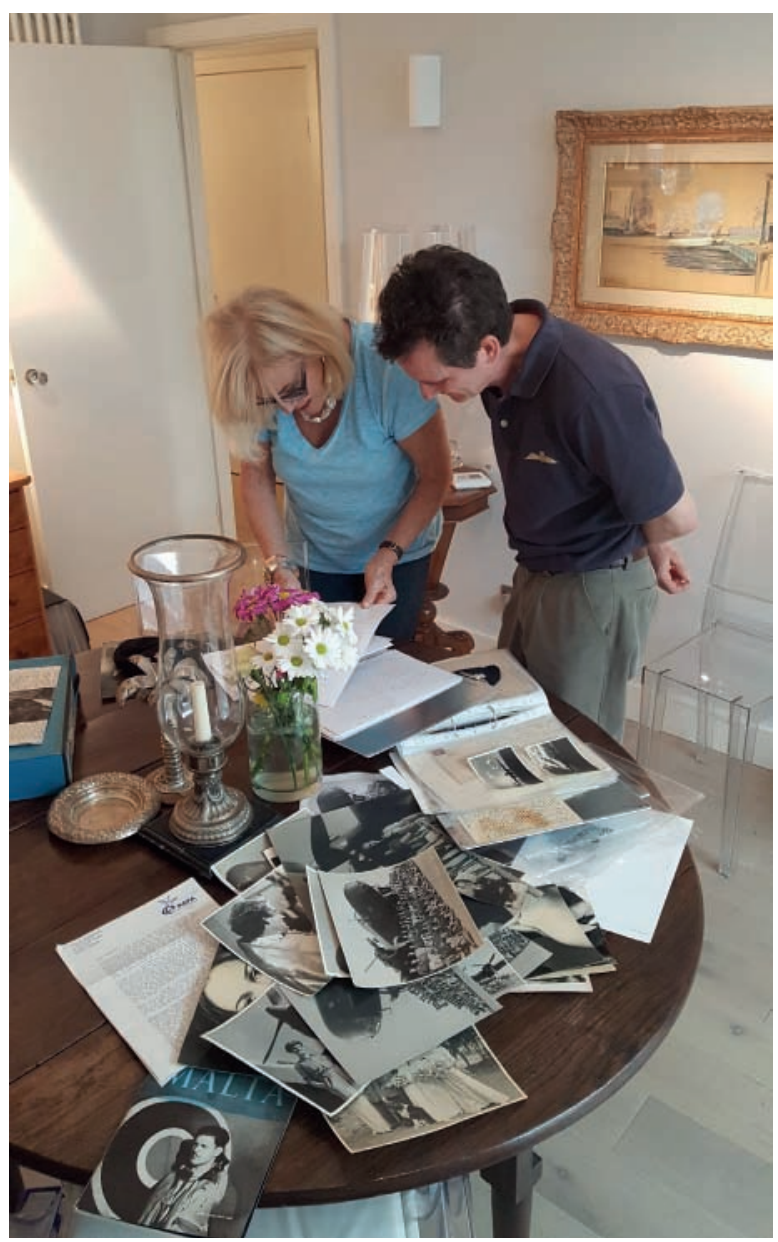

18. ábra. Bird őrnagy lányával Penelope Bird Barnarddal nézegetjük édesapja dokumentumait londoni lakásán 2017. május 14-én. (Fotó: Nagy Gábor).
Időközben a kutatásunkhoz csatlakozott a Magyarországon élő francia Hubert Warsmann is, akit már régóta foglalkoztatott Tilmont Marcel története tekintve, hogy ő volt az egyetlen francia katona, aki a II. világháborúban Magyarországon elesett. Több személyes találkozó után Hubert felvetette egy emlékmü ötletét, amelyet én is jó gondolatnak tartottam, de ennek megszervezése és kivitelezése jócskán meghaladta volna a lehetőségeimet. Ő viszont egy remek javaslattal állt elö. Tekintve, hogy a repülögépen három nemzet katonái vesztették életüket, terjesszük elő a javaslatot a három ország nagykövetségének. Ennek pedig első lépése lehetne, ha egy részletes előadás

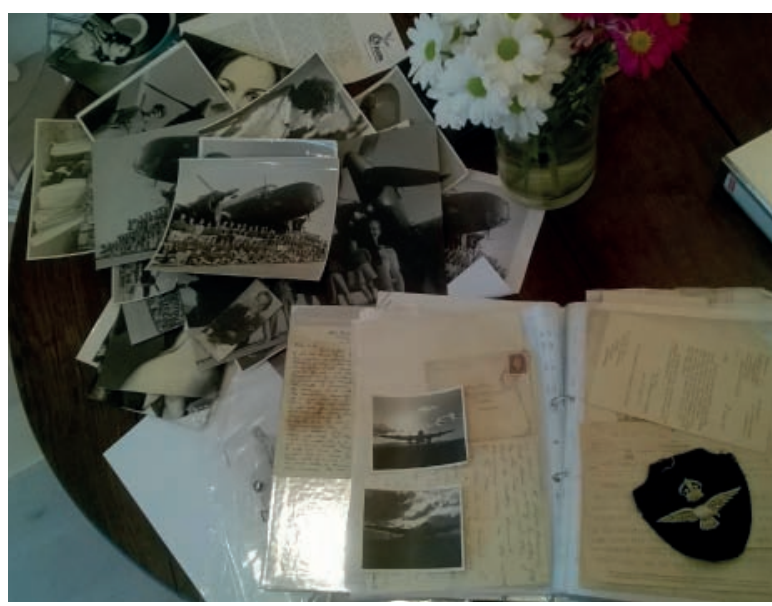

19. ábra. Penelope Bird Barnard dokumentumai édesapjáról. Valójában ez csak egy kis része a teljes anyagnak. (Fotó: Nagy Gábor)

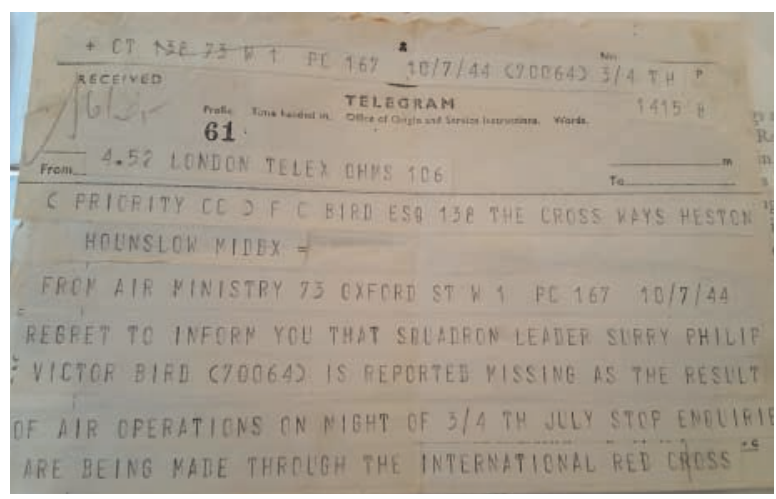

20. ábra. . A Légügyi Minisztérium telegramja, amelyben tudatták a családdal Bird örnagy eltünését. (Forrás: Penelope Bird Barnard) 


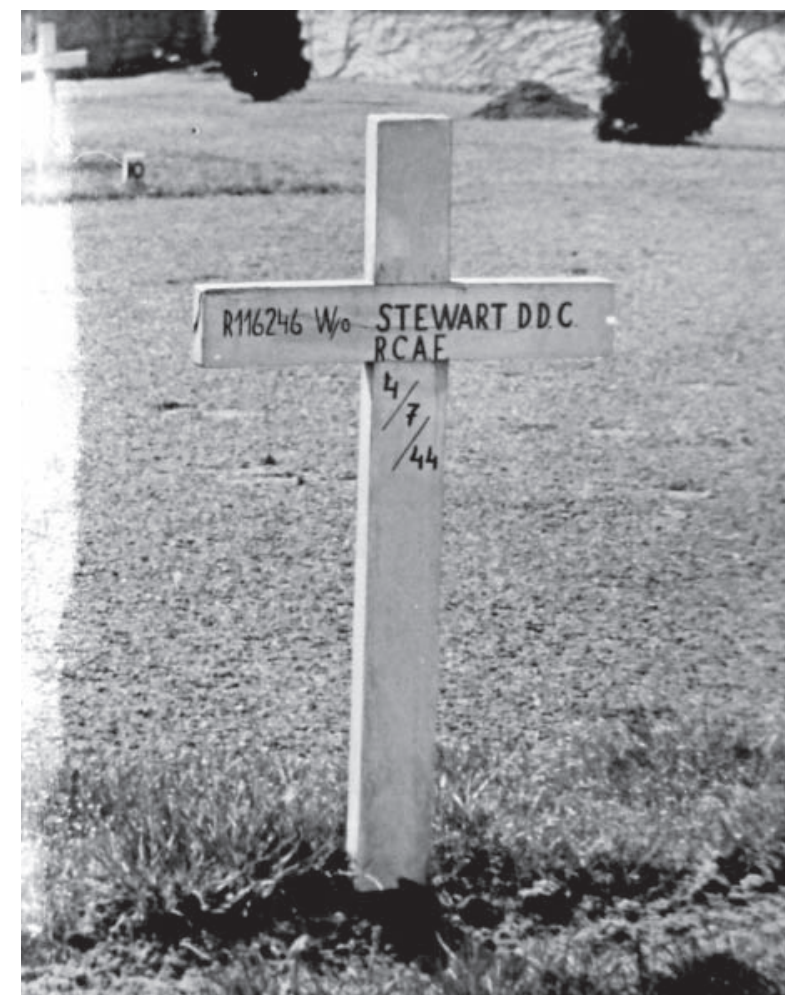

21. ábra. Donald David Charles Stewart ideiglenes fejfája a solymári katonai temetőben. (Forrás: Oliver Clutton-Brock).

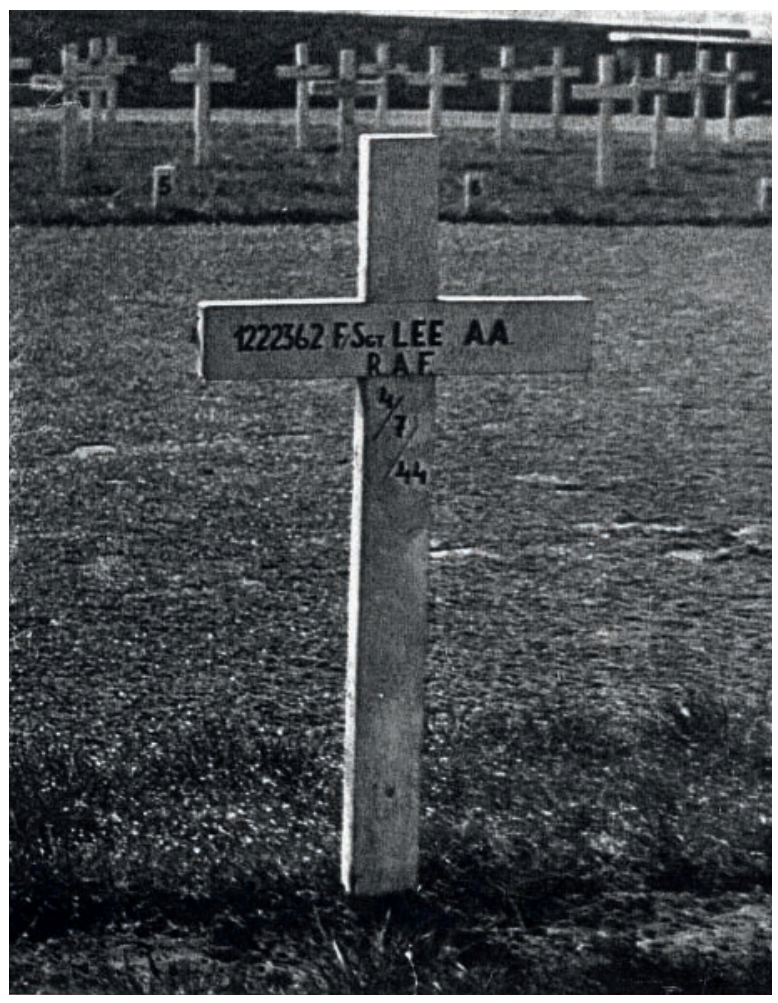

22. ábra. Arthur Archer Lee ideiglenes fejfája a solymári katonai temetőben. (Forrás: Lee családja).

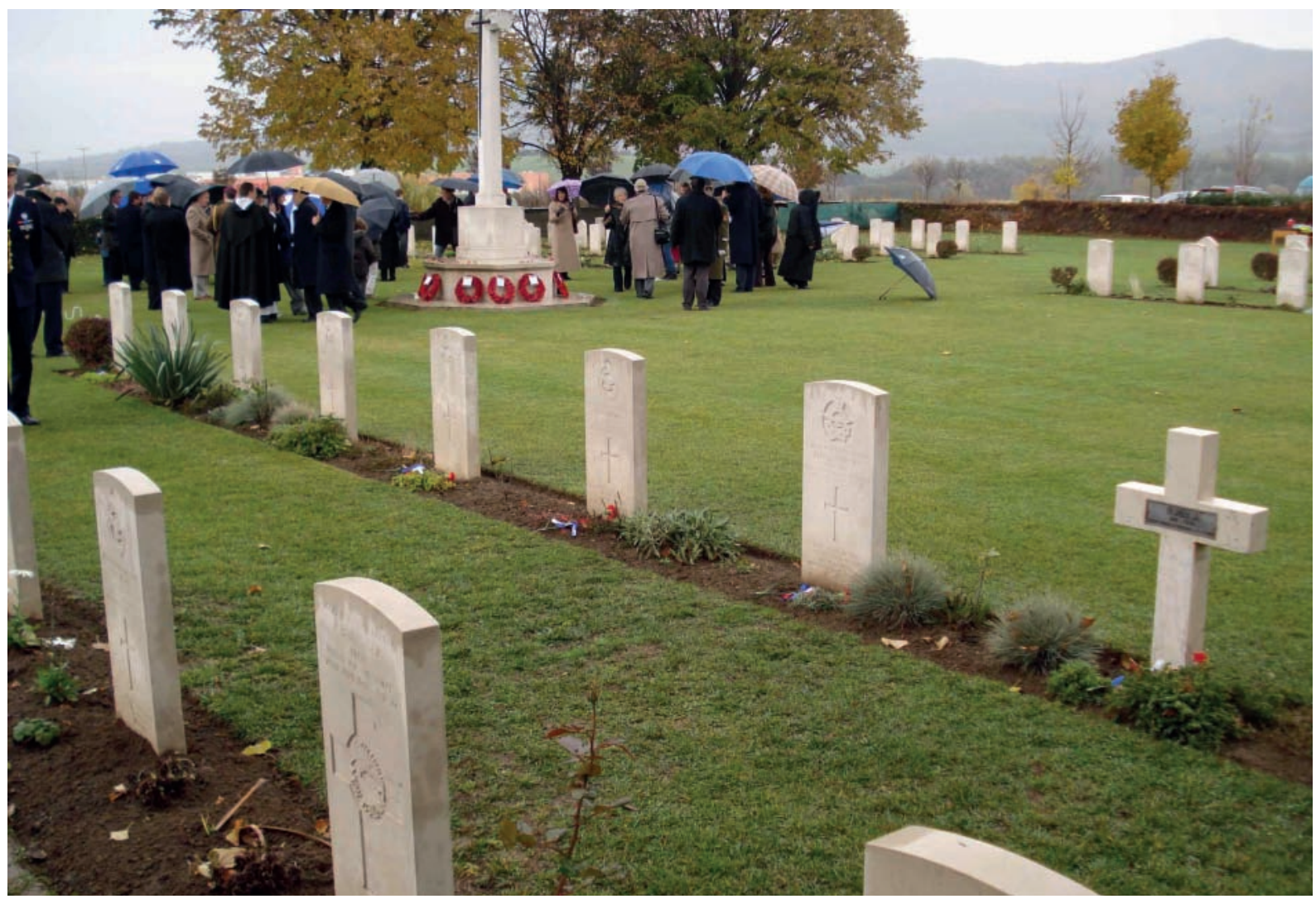

23. ábra. A Halifax legénységének sírjai a solymári angol katonai temetőben. (Fotó: Nagy Gábor). 
keretében elmondanánk nekik a teljes történetet. Mivel Hubertnek igen jó kapcsolatai voltak a három nagykövetséggel, egyeztetésbe kezdett. Ennek eredményeként végül a Francia Nagykövetség egy konferenciát szervezett, amelyre 2019. október 4-én került sor a budapesti Francia Intézetben. Az eseményre Penelope is meghívást kapott, akivel előző nap kimentünk arra a helyre, amit oly régóta szeretett volna megnézni. Mezőcsokonya külterületére, ahol édesapja elesett. Megható pillanat volt ez mindkettőnk számára. Végül az emlékmű tervezete teljes támogatást kapott és jelen sorok írásakor az ügy még folyamatban van.

Mezőcsokonya mai és egykori lakosai 2020. február 29-én ismerhették meg a teljes történetet egy elöadás keretében, amelyre Sudár Zoltán polgármester kért fel, és amire közel százan voltak kíváncsiak.

\section{Végső nyughely}

A háború után a Brit hadvezetés külön alakulatot állított fel az elesett és eltűnt repülőszemélyzetek felkutatására. Az Eltűntek után Kutató és Nyomozó Szolgálat (Missing Research and Enquiry Service - továbbiakban MRES) részlegei a számukra kijelölt földrajzi területen elesett repülőszemélyzetek után nyomoztak. Magyarország a Közép Mediterrán Térséggel foglalkozó 5. MREU részleghez tartozott, központjuk Ausztriában volt. Sem fizikai, sem lelki szempontból nem volt könnyű feladatuk, különösen a közép-európai országokban nem. Nyomozásaik során a felszereléseik rendszeresen eltüntek, sőt volt olyan is, hogy a teherautójukat lopták el. Emiatt egy embernek folyamatosan a felszerelési tárgyakra kellett vigyáznia, a gépjárművet pedig nem hagyhatta magára. Mindezek mellett a helyi lakosság a legkevésbé sem volt együttműködő. Legtöbbször úgy tettek, mintha semmit sem tudnának és csak vonakodva adtak információt „ingyen”. Így Európa ezen részén megszokott gyakorlattá vált, hogy a nyomozók fizettek az információkért, a roncsmaradványokért, vagy a halottaktól elvett személyes és felszerelési tárgyakért.

A nyomozók végül az 1947. március 18-án kelt jelentésükben számoltak be a helyszínen végzett munkájukról:

„...3. KOZEPNYRSEN (M.R. 8066, Sh. Y-4, 1/250,000 NAGYKANIZSA, Jugoszlávia) 8 ismeretlen katona után végzett nyomozás során kiderült, hogy ök egy repülőgépről származnak, állítólag egy Halifaxról, ami 1944. július 2-án, vagy 3-án vagy 4-én zuhant le. MEZOCSKONYA (M.R. 8067, Sh. Y-4, 1/250,000) jegyzője szerint, illetve a kikérdezett helybéliek szerint a repülőgépet egy vadászgép lötte le körülbelül 01.00 órakor. A gép tett egy kört a falu felett, megpróbált kényszerleszállást végrehajtani, de nekiment egy kerítésnek, átfordult majd kigyulladt, ami után több kisebb robbanás volt hallható. Nyolc holttestet találtak, a talált iratokat a katonaság elvitte, a holttesteket pedig közös sírba temették egy azonossági táblával együtt, amit a helyszínen találtak. Nem sokkal ezután a helyi katonaság az egész roncsot elszállította.

4. A lezuhanás helyére kilátogatva a nyomozótisztünk csak kisebb alumínium darabokat talált, amelyeken semmiféle azonosításra alkalmas jelzés nem volt, illetve egy fém darabot, ami valószínüleg az egyik Merlin motorról származhatott rajta egy számmal:

D. $16951 \mathrm{~F}$.

A motort nem sikerült lenyomozni, ezért úgy tünik, hogy az egyetlen esély az azonositásra a már említett azonossági lap.

5. Az exhumálás és a maradványok begyüjtése megtörtént, és mivel az azonossági lapot nem találták meg, így a JP286 Halifax legénységének egyik tagját sem lehetett személy szerint azonosítani. Azonban tekintve azt a tényt, hogy a maradványok között találtak egy a Szárazföldi Hadseregnél (Army) rendszeresített kabátot, tovább erősíti azt a feltételezést, hogy az ismeretlen katonák ehhez a repülögéphez tartoztak, mivel a kérdéses éjszakán csupán egy olyan repülőgép tünt el, amelynek a fedélzetén a Szárazföldi Hadsereg (Army) tisztjei tartózkodtak. Valószínüleg ök a repülögép első célpontja felett már kiugrottak és egyikőjük a gépben hagyta a kabátját.

6. A testek a Budapesti Brit Katonai Temetöbe lettek szállítva, ahol a 2. parcella, E sorának 1.,2., 3., 4., 5.,6.,7. és 8. sírhelyén lettek eltemetve, erröl a jelentést mellékeltük. A helybéliek szerint a sírban nyolc test feküdt, de az exhumálás során teljes bizonyossággal hét holtestet találtak, ám feltételezhetően nyolcat. A legénység elhantolásának körülményei és állapota miatt nem lehet minden kétséget kizáróan megállapitani, hogy nyolc holttest volt-e a sírban. ..."5 (21., 22. és 23. ábra).

Bird őrnagy családját 1947. július 9-én értesítette a Légügyi Minisztérium a legénység megtalálásának körülményeiről és a solymári temetőben létesített közös, végső nyughelyről. Itt ért véget e nyolc bátor fiatal útja, akik életüket adták a szabadságért és e nyolc sírban nyugszik Magyarország háborús kiugrási kísérletének egy cseppnyi fejezete is. 


\section{Irodalom}

Clutton-Brock, O. 2017: Trusty to the end - The history of 148 (Special duties) squadron 1918-1945

GREHAN, J. \& MACE, M. 2012: Unearthing Churchill's secret army The official list of SOE casualties and their stories

HADAWAY, S. 2012: Missing believed killed - Casualty policy and the Missing Research and Enquiry Service

Ogden, A. 2010: Through Hitler's Back Door - SOE Operations in Hungary, Slovakia, Romania and Bulgaria, 1939-1945,

Veress, L-L. 1995: Clear the line-Hungary's struggle to leave the Axis during the Second World War

MACLAREN, R. 1981: Canadians behind enemy lines, 1939-1945

148. SZÁZAD HADMŰVELETI NAPLÓJA (Operational Record Book, 148. squadron) http://www.cbc.ca/xcompany/dispatches/brave-hungarian-canadianfinds-no-luck-in-war

http://www.cbc.ca/xcompany/dispatches/the-man-who-didnt-exist https://www.findagrave.com/memorial/56906758/stephen-maitland http://www.specialforcesroh.com/archive/index.php/t-19930.html https://en.wikipedia.org/wiki/Peter_Boughey https://en.wikipedia.org/wiki/Basil_Davidson 